\title{
Exploring Rain as Source of Biological Control Agents for Fire Blight on Apple
}

Marco E. Mechan Llontop ${ }^{1}$, Kelly Hurley ${ }^{1}$, Long Tian ${ }^{1}$, Vivian A. Bernal Galeano ${ }^{1}$,
Hans K. Wildschutte ${ }^{2}$, Sasha C. Marine ${ }^{3}$, Keith S. Yoder ${ }^{1,4}$ and Boris A. Vinatzer ${ }^{1 *}$

${ }^{1}$ School of Plant and Environmental Sciences, Virginia Tech, Blacksburg, VA, United States, ${ }^{2}$ Department of Biological Sciences, Bowling Green State University, Bowling Green, OH, United States, ${ }^{3}$ Department of Biochemistry, Virginia Tech, Blacksburg, VA, United States, ${ }^{4}$ Alson H. Smith Jr. Agricultural Research and Extension Center, Virginia Tech, Winchester, $\checkmark A$, United States

Poor survival on plants can limit the efficacy of Biological Control Agents (BCAs) in the field. Yet bacteria survive in the atmosphere, despite their exposure to high solar radiation and extreme temperatures. If conditions in the atmosphere are similar to, or more extreme than, the environmental conditions on the plant surface, then precipitation may serve as a reservoir of robust BCAs. To test this hypothesis, two hundred and fifty-four rain-borne isolates were screened for in vitro inhibition of Erwinia amylovora, the causal agent of fire blight, as well as of other plant pathogenic bacteria, fungi and oomycetes. Two isolates showed strong activity against $E$. amylovora and other plant pathogenic bacteria, while other isolates showed activity against fungal and oomycete pathogens. Survival assays suggested that the two isolates that inhibited E. amylovora were able to survive on apple blossoms and branches similarly to E. amylovora. Pathogen population size and associated fire blight symptoms were significantly reduced when detached apple blossoms were treated with the two isolates before pathogen inoculation, however, disease reduction on attached blossoms within an orchard was inconsistent. Using whole genome sequencing, the isolates were identified as Pantoea agglomerans and $P$. ananatis, respectively. A UV-mutagenesis screen pointed to a phenazine antibiotic $D$-alanylgriseoluteic acid synthesis gene cluster as being at the base of the antimicrobial activity of the $P$. agglomerans isolate. Our work reveals the potential of precipitation as an under-explored source of BCAs, whole genome sequencing as an effective approach to precisely identify BCAs, and UVmutagenesis as a technically simple screen to investigate the genetic basis of BCAs. More field trials are needed to determine the efficacy of the identified BCAs in fire blight control.

Keywords: rain, fire blight, biocontrol, genome-based identification, UV mutagenesis

\section{INTRODUCTION}

There has been a growing effort in scouting for bacteria and fungi to be deployed as biological control agents (BCAs) against crop pests (Jaffuel et al., 2019) and diseases (Durán et al., 2018). The motivation behind this effort includes the emergence of fungicide resistance in plant pathogenic fungi and antibiotic resistance in plant pathogenic bacteria, as well as an increase in consumer 
demand for crops produced without synthetic pesticides (Dean et al., 2012; Reganold and Wachter, 2016; Sundin and Wang, 2018).

One plant disease that is challenging to control is fire blight of apple (Malus $x$ domestica) and pear (Pyrus communis) (Norelli et al., 2003). Since this bacterial disease was first reported in the United States in the 1870s, the causal agent, Erwinia amylovora, has spread to Europe, Asia, and Africa and New Zealand, causing significant economic losses (CABI, 2018). The main vectors of transmission are rainfall and pollinating insects. E. amylovora mainly invades plants through open blossoms and wounds and infects trees systemically through the vascular system (Thomson, 1985; Koczan et al., 2011). The first sign of disease consists of droplets of bacterial ooze on the surface of infected tissues. Blossoms and young fruits are later aborted, followed by necrosis and wilting of leaves and shoots on infected branches. In the worst case, the entire tree may die (Norelli et al., 2003).

The antibiotic streptomycin sulfate is generally an efficient method to control fire blight, but antibiotic use in crop production is illegal in many countries, and antibiotic-resistant strains have emerged in several apple and pear growing regions (Loper et al., 1991; McManus and Jones, 1994; Russo et al., 2008; Förster et al., 2015; Tancos et al., 2015). Therefore, BCAs for fire blight control have been explored for many years (Ishimaru et al., 1988). Currently available commercial products include: BlightBan ${ }^{\mathrm{TM}}$ A506 [Pseudomonas fluorescens A506, isolated from leaves of pear trees (Wilson and Lindow, 1992)], BlightBan ${ }^{\text {TM }}$ C9-1 [Pantoea vagans C9-1, isolated from apple stem tissue (Ishimaru et al., 1988)], Serenade Optimum $^{\mathrm{TM}}$ (Bacillus subtilis QST713, isolated from soil), Double Nickel ${ }^{\mathrm{TM}}$ (Bacillus amyloliquefaciens D747, isolated from soil), Biopro ${ }^{\mathrm{TM}}$ (Bacillus subtilis BD170), Bloomtime Biological $^{\mathrm{TM}}$ [Pantoea agglomerans E325, isolated from apple blossoms (Pusey, 1999)], and Blossom Protect ${ }^{\text {TM }}$ (Aureobasidium pullulans strains DSM 14940 and DSM 14941, isolated from leaves of apple trees in 1989, Germany). Disease suppression by these BCAs is achieved by multiple modes of action including: the production of antimicrobial compounds (Ishimaru et al., 1988; Temple et al., 2004), colonization rates higher than those of the pathogen (Wilson and Lindow, 1994), competition for nutrients (Wilson and Lindow, 1992; Lindow, 1993), induction of plant defenses (Van Wees et al., 1997; Pieterse et al., 2014; Alamri et al., 2019), or a combination of mechanisms (Neeno-Eckwall et al., 2001).

A major hurdle to the introduction of commercial BCAs is their regulation. Precise identification and thorough characterization are necessary to exclude the potential for a BCA to cause disease in plants, animals, or humans. In fact, Bloomtime Biological ${ }^{\mathrm{TM}}$ is not available in the European Union because of safety concerns in regard to the species P. agglomerans, which has been reported to occasionally cause human infections (Cruz et al., 2007; Büyükcam et al., 2018). Precise genomebased classification and identification methods, such as the Life Identification Number (LIN) system implemented in the LINbase web server (Tian et al., 2019), could aid in regulation of BCAs, but those methods have not been thoroughly explored within this context.
Another challenge with BCAs is that their efficacy under field conditions is more variable than synthetic pesticides since BCAs contain living organisms, whose survival on plant surfaces and/or internal tissues depends on environmental conditions (Sundin et al., 2009; Bonaterra et al., 2012). This is especially true for BCAs that are applied to aerial parts of plants, where conditions can change rapidly in regard to temperature, humidity, and solar radiation. In a previous study (Failor et al., 2017), we isolated 33,134 bacterial strains from precipitation, of which 1144 strains were found to be putative ice nucleation active strains. Later characterization determined that 551 of those strains (i) did not have ice nucleation activity and (ii) were members of plant-associated species within the genera Bacillus, Pseudomonas, and Pantoea. These plant-associated species are also known to include BCAs. Because these bacterial strains were isolated from precipitation, we hypothesized that they may resist environmental stresses (solar radiation, temperature, moisture, etc.) better than bacteria isolated from soil or plant tissues. Therefore, we screened 254 of these ice nucleation inactive rain-borne isolates for inhibition of E. amylovora and for their ability to persist on apple trees. The strongest inhibitors of E. amylovora growth in vitro were then tested under laboratory and field conditions to evaluate survival on apple branches and blossoms and for suppression of fire blight on apple blossoms. The most promising BACs were then identified to species using genome-based methods, including the LINbase Web server (Tian et al., 2019), and the genetic basis of the biocontrol activity for one of the bacteria was explored using a combination of UV-mutagenesis and genome sequencing.

\section{MATERIALS AND METHODS}

\section{In vitro Screening for Inhibition of E. amylovora Growth}

A dual culture assay was used to detect antimicrobial activity in 254 rain-borne bacteria (listed in Supplementary Table S1) against two isolates of Erwinia amylovora from Northern Virginia (BAV5616 and BAV5617). The assay was performed in Petri dishes containing yeast extract dextrose agar NYDA (Nutrient agar $23 \mathrm{~g} \mathrm{l}^{-1}$, dextrose $10 \mathrm{~g} \mathrm{l}^{-1}$, yeast extract $\left.5 \mathrm{~g} \mathrm{l}^{-1}\right) .100 \mu \mathrm{l}$ of $E$. amylovora suspensions were spread on each plate and up to five $10 \mu \mathrm{l}$-droplets of suspension of rain-isolated bacteria were placed at equal distance from each other. In an initial screening, suspensions were made by adding a loop-full of rain-borne bacteria to $1 \mathrm{ml}$ of sterile $50 \mathrm{mM}$ potassium phosphate buffer $(\mathrm{pH}$ 7.0). In follow-up experiments, concentrations of putative BCAs were adjusted to an optical density of 0.1 at $600 \mathrm{~nm}\left(\mathrm{OD}_{600}\right)$. Suspensions of increasing concentration of E. amylovora were spread on plates $\left(\mathrm{OD}_{600}\right.$ of $0.001,0.01,0.1$, and 1 , with the latter corresponding to a concentration of $3 \times 10^{9} \mathrm{CFU} \mathrm{ml}^{-1}$ ). Plates were incubated at $28^{\circ} \mathrm{C}$ for $24 \mathrm{~h}$. Antagonistic activity was quantified by the diameter of the inhibition zone forming around the rain-isolated bacteria. Rain-isolated bacteria that showed the most pronounced inhibition were also screened for activity against other economically important bacterial (10 isolates), 
fungal (5 isolates) and oomycete (1 isolate) plant pathogens (Table 2 and Supplementary Table S2) using similar protocols.

The two rain-isolated bacteria, BAV2934 and BAV3296, that showed the strongest inhibition of E. amylovora in vitro were chosen for further characterization. To facilitate re-isolation from plants, rifampicin-resistant mutants were selected for these strains and for E. amylovora. This was done by growing strains on NYDA solid medium containing $20 \mathrm{mg} \mathrm{ml}^{-1}$ of antibiotic. Colonies that grew at this concentration were then serially transferred to media with increasing antibiotic concentration (50, 100, 150, and $200 \mathrm{mg} \mathrm{ml}^{-1}$ ).

\section{Survival Assay Under Environmental Conditions}

To compare the survival of BAV2934, BAV3296, and E. amylovora rifampicin-resistant mutant strains (BAV5616), branches of potted 5-year old apple trees cultivar "Golden delicious" were spray-inoculated to run-off at an $\mathrm{OD}_{600}$ of 0.1 and placed on the roof of a three-story research building. Apple trees were exposed to the outdoor environment for the duration of the experiment. The non-pathogenic Escherichia coli strain DH5-Alpha was included for comparison. Bacterial population sizes were determined on the day of inoculation, and 4,8 , and 12 days after inoculation by dilution-plating on NYDA containing $200 \mathrm{mg} \mathrm{ml}^{-1}$ rifampicin.

\section{Assay of Inhibitory Activity Against E. amylovora on Detached Apple Blossoms}

Blossoms of apple cultivar "Golden Delicious" were detached at the first bloom stage (central blossom just opened) and maintained with the cut pedicel submerged in $10 \%$ sucrose solution. Potential BCAs were cultured on NYDA plates for $24 \mathrm{~h}$ at $28^{\circ} \mathrm{C}$, and cell suspensions were prepared in $10 \mathrm{mM} \mathrm{MgSO}_{4}$ containing $0.01 \%$ of Silwet. BlightBan ${ }^{\mathrm{TM}}$ A560 (active ingredient: P. fluorescens strain A560; NuFarm Americas, Burr Ridge, IL, United States) and FireWall ${ }^{\mathrm{TM}}$ 17WP (active ingredient: streptomycin sulfate; AgroSource, NJ, United States) were diluted to $0.8 \mathrm{~g} \mathrm{l}^{-1}$ water and $2 \mathrm{~g}^{-1}$ water, respectively, following manufacturer's instructions. A rifampicin-resistant mutant strain of E. amylovora was cultured on NYDA plates containing $200 \mathrm{mg}$ $\mathrm{ml}^{-1}$ rifampicin for $24 \mathrm{~h}$ at $28^{\circ} \mathrm{C}$, and a cell suspension was prepared in $10 \mathrm{mM} \mathrm{MgSO}_{4}$ and $0.01 \%$ of Silwet.

Six individual detached blossoms were pre-treated with one of the following treatments: bacterial suspension (BAV2934, BAV3296 or E. coli DH5-Alpha) at a concentration of $10^{9} \mathrm{CFU}$ $\mathrm{ml}^{-1} ; 10 \mathrm{mM} \mathrm{MgSO}_{4}$ (mock treatment negative control), or a commercial product (BlightBan ${ }^{\mathrm{TM}}$ A560 or FireWall ${ }^{\mathrm{TM}} 17 \mathrm{WP}$ ). Detached blossoms were pre-treated by dipping the blossoms into the bacterial suspension or commercial product for $10 \mathrm{~s}$. Blossoms were then allowed to air-dry for $2 \mathrm{~min}$, enclosed in a planting tray, and incubated at room temperature for $48 \mathrm{~h}$. The experiment was repeated a total of four times.

Pre-treated blossoms were then inoculated with E. amylovora

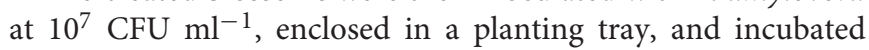
at room temperature for $72 \mathrm{~h}$. Pathogen population sizes were determined in the receptacle and pedicel separately by grinding plant tissue followed by dilution-plating on NYDA supplemented with $200 \mathrm{mg} \mathrm{ml}^{-1}$ of rifampicin. Disease severity was calculated as fraction of the length of the necrotic pedicel divided by the total pedicel length.

\section{Disease Suppression Assays on Attached Blossoms in an Orchard}

Field experiments were conducted in April 2018 and April 2019 in an experimental orchard at Virginia Tech's Kentland Farm (McCoy, VA, United States). Dates of treatments and weather conditions are reported in Supplementary Table S4. Clusters of apple blossoms of the varieties "Golden Delicious," "York Imperial," "Rome Beauty" and "Empire" at the first bloom stage were spray-inoculated to the point of run off. Inoculations were performed during morning hours to avoid warm temperatures that may affect bacterial attachment and survival. Between 20 and 30 blossom clusters were randomly pre-treated using BAV2934 $\left(10^{9} \mathrm{CFU} \mathrm{m}^{-1}\right)$, BAV3296 $\left(10^{9} \mathrm{CFU} \mathrm{ml}^{-1}\right)$, FireWall ${ }^{\mathrm{TM}} 17 \mathrm{WP}$ (2 $\left.\mathrm{g} \mathrm{l}^{-1}\right)$, and BlightBan ${ }^{\mathrm{TM}}$ A506 (0.8 $\mathrm{g}$ diluted in $1 \mathrm{l}$ ) as described above. $10 \mathrm{mM} \mathrm{MgSO}_{4}$ was used as mock treatment negative control. In 2018, three "Golden Delicious" and three "York" trees located in different rows in an orchard were inoculated as replicates, with each tree receiving all treatments. In 2019, three "Golden Delicious" and two "Empire" and two "Rome" apple trees located in different rows in an orchard were inoculated as replicates, with each tree receiving all treatments. Pre-treated blossoms were allowed to air-dry before inoculation

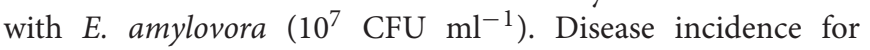
each treatment was evaluated as percentage of symptomatic clusters out of all clusters. All data were analyzed using JMP statistical software (Statistical Analysis Systems Institute, Cary, NC, United States). We performed a one-way ANOVA analysis of variance, using a significance level of 0.05 , to test the null hypothesis that treatments do not differ in controlling fire blight. Tukey-Kramer HSD was used for all pairwise comparisons in our detached and attached blossoms assays. Graphs were plotted in RStudio version 1.1.456 (RStudio, 2015).

\section{UV Mutagenesis Screen to Identify the Molecular Basis of Growth Inhibition}

To identify genes necessary for the suppression of E. amylovora, mutants of BAV2934 were generated by UV radiation following the protocol by Barrick (2014) with small modifications. Briefly, an overnight bacterial culture was resuspended in water at an $\mathrm{OD}_{600}$ of 0.1 . $10 \mu \mathrm{l}$ droplets were subjected to $10,000 \mu \mathrm{J}$ of UV radiation utilizing a UV Stratalinker (Stratagene UV Stratalinker 1800). UV treated cells were plated onto TSA medium and incubated for $24 \mathrm{~h}$ at $28^{\circ} \mathrm{C}$. All single colonies were tested for inhibitory activity following the plate assay as described above. Any putative bacterial colony that lost inhibitory activity against E. amylovora was confirmed in subsequent tests.

\section{Genome Sequencing}

Genomic DNA from strains BAV2934 and BAV3296 was extracted using the Genomic DNA purification kit 
(PUREGENE - Gentra Systems, United States) according to the manufacturer's protocol. The DNA concentration and quality were evaluated by UV spectrophotometry (NanoDrop 1000, Thermo Fisher Scientific, United States) and visualized on a $1 \%$ agarose gel. DNA library preparation and Paired-end (PE150) sequencing was performed on the Illumina HiSeq 2500 at the Biocomplexity Institute at Virginia Tech (Blacksburg, VA, United States).

Isolate BAV2934 was also sequenced using Oxford Nanopore Technologies' (Oxford, United Kingdom) MinION. A total of $3 \mu \mathrm{g}$ of purified bacterial DNA was treated with RNase A $100 \mathrm{mg}$ $\mathrm{ml}^{-1}$ (1 $\mu \mathrm{l}$ for $100 \mu \mathrm{l}$ of gDNA) and the Short Read Eliminator Kit (Circulomics, Baltimore, MD, United States), according to the manufacturer's protocol. The purified bacterial DNA was used to prepare a sequencing library with the $1 \mathrm{D}$ genomic DNA ligation kit SQK-LSK109 (Oxford Nanopore Technologies, United Kingdom). Sequencing was performed with a FLOMIN106 (R 9.4.1) flow cell for $48 \mathrm{~h}$.

\section{Genome Analysis}

FastQC (Andrews, 2010) was used to assess sequencing reads for quality control. Reads were trimmed using Trimmomatic (Bolger et al., 2014) to remove adapter sequences and low quality reads $(Q<30)$. De novo assemblies were generated using SPAdes (Bankevich et al., 2012).

The fast5 files generated by MinION sequencing of the BAV2934 genome were base-called using guppy (version 3.3.2). A hybrid assembly using both Illumina and ONT reads was performed using Unicycler v0.4.7 (Wick et al., 2017) with default parameters. Bandage (Wick et al., 2015) was used to visualize the bacterial assembly graph. Prokka (Seemann, 2014) was used to annotate the assembled genome sequence.

Genomic DNA of five BAV2934 UV-induced mutants was pooled and sequenced using Illumina as described above. Mutations were identified by mapping reads against the BAV2934 hybrid assembly. In brief, a reference genome index was pre-built with HiSat2 (Kim et al., 2015). Illumina paired-end reads were aligned to the reference genome using SAMtools (Li et al., 2009) and VarScan (Koboldt et al., 2009) was used for calling variants selecting parameters for pooled samples (-min-coverage8 -minvar-freq 0.15 - $p$-value 0.05$)$. Read coverage of each gene was determined using bbmap (Bushnell, 2014).

Assembled genome sequences in fasta format were used for strain identification at the LINbase website at linbase.org (Tian et al., 2019) using the "Identify using a genome sequence" function.

The antibiotic and Secondary Metabolite Analysis Shell [antiSMASH (Medema et al., 2011)], which is capable of identifying loci that cover the whole range of known secondary metabolite compound classes, was used to identify gene clusters in the wildtype strain BAV2934.

\section{Analysis of Blossom Microbiomes}

"Golden Delicious" apple blossoms were inoculated in an orchard

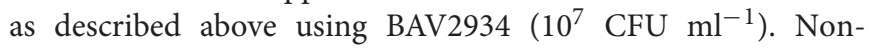
inoculated blossoms served as negative control. Fifteen blossoms per treatment were collected into a clean Ziploc plastic bag on day 0 (day of inoculation), 5 days after inoculation, and 10 days after inoculation. Blossoms were immediately transported to the laboratory and processed. Culturable bacterial population sizes were determined on TSA by dilution-plating.

For the culture-independent microbiome analysis, $300 \mathrm{ml}$ of sterile distilled water was added to each Ziploc bag containing the blossoms. Samples were sonicated for $10 \mathrm{~min}$ using a 1520 BRANSON sonicator (Branson Ultrasonics, Danbury, CT, United States). The liquid was then vacuum-filtrated through a $0.2 \mu \mathrm{m}$ pore-size filter membrane (Supor ${ }^{\circledR} 200$ PES membrane Disk Filter, PALL Corporation, Port Washington, NY, United States). Genomic DNA extraction from filters was performed using the DNeasy PowerWater kit (Qiagen, Germantown, MD, United States) according to the manufacturer's protocol. DNA concentration and quality were determined by NanoDrop 1000 (Thermo Fisher Scientific, Waltham, MA, United States) and visualization on a $1 \%$ agarose gel. Primers 799F (antichloroplast, 5'AACMGGATTAGATACCCKG3') and 1115R ("universal,"5'AGGGTTGCGCTCGTTG3') were used to amplify and sequence the V4 hypervariable region of the $16 \mathrm{~S}$ rRNA gene. All steps from PCR to paired-end $(2 \times 300 \mathrm{bp})$ amplicon sequencing on the Illumina MiSeq platform were performed at Molecular Research LP (MR DNA ${ }^{\mathrm{TM}}$, Shallowater, TX, United States). QIIME version 1.9.1 was used for amplicon data analysis (Caporaso et al., 2010). Briefly, quality filtered paired-end reads (phred quality scores above 30) were joined together in a single read. Operational taxonomic units (OTUs) were picked using the open-reference pipeline at 97\% sequence similarity using UCLUST as the clustering tool and the SILVA database (Quast et al., 2013). All OTUs unassigned or assigned to mitochondria, chloroplast and Cyanobacteria were removed. Data was visualized in RStudio version 1.1.456 using the Phyloseq 1.19.1 (McMurdie and Holmes, 2013) and ggplot2 2.2.1 packages.

\section{RESULTS}

\section{Rain-Borne Bacteria Inhibit Erwinia amylovora and Other Plant Pathogens in vitro}

Nine out of 254 tested rain-isolated bacteria (Supplementary Table S1) displayed an inhibitory effect against E. amylovora during initial in vitro dual culture screening (Figure 1A). These nine bacteria had been previously identified (Failor et al., 2017) by $16 \mathrm{~S}$ rRNA sequencing as members of the genera Pseudomonas, Pantoea, and Bacillus (Table 1). A more stringent assay using higher concentrations of E. amylovora allowed us to identify two isolates (BAV2934 and BAV3296) from the genus Pantoea with the highest inhibitory effect, as measured by the diameter of the inhibition zone that they induced (Figure 1B). BAV2934 and BAV3296 were chosen for further characterization.

We also evaluated the inhibitory effect of the nine bacteria that had shown activity against E. amylovora for activity against 
A

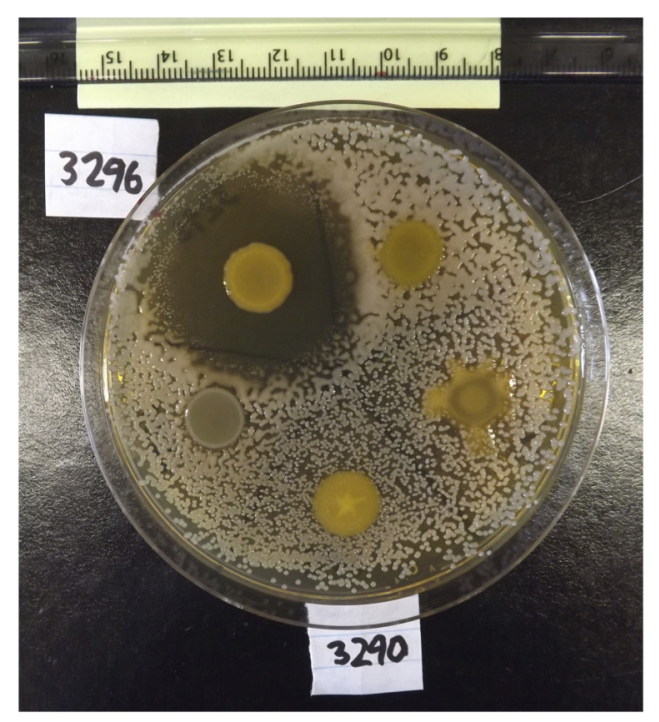

B

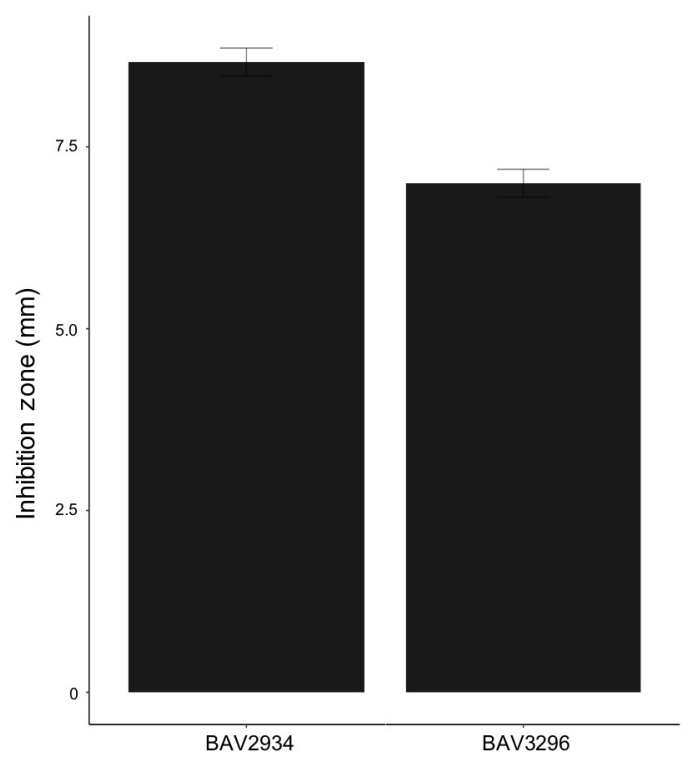

C

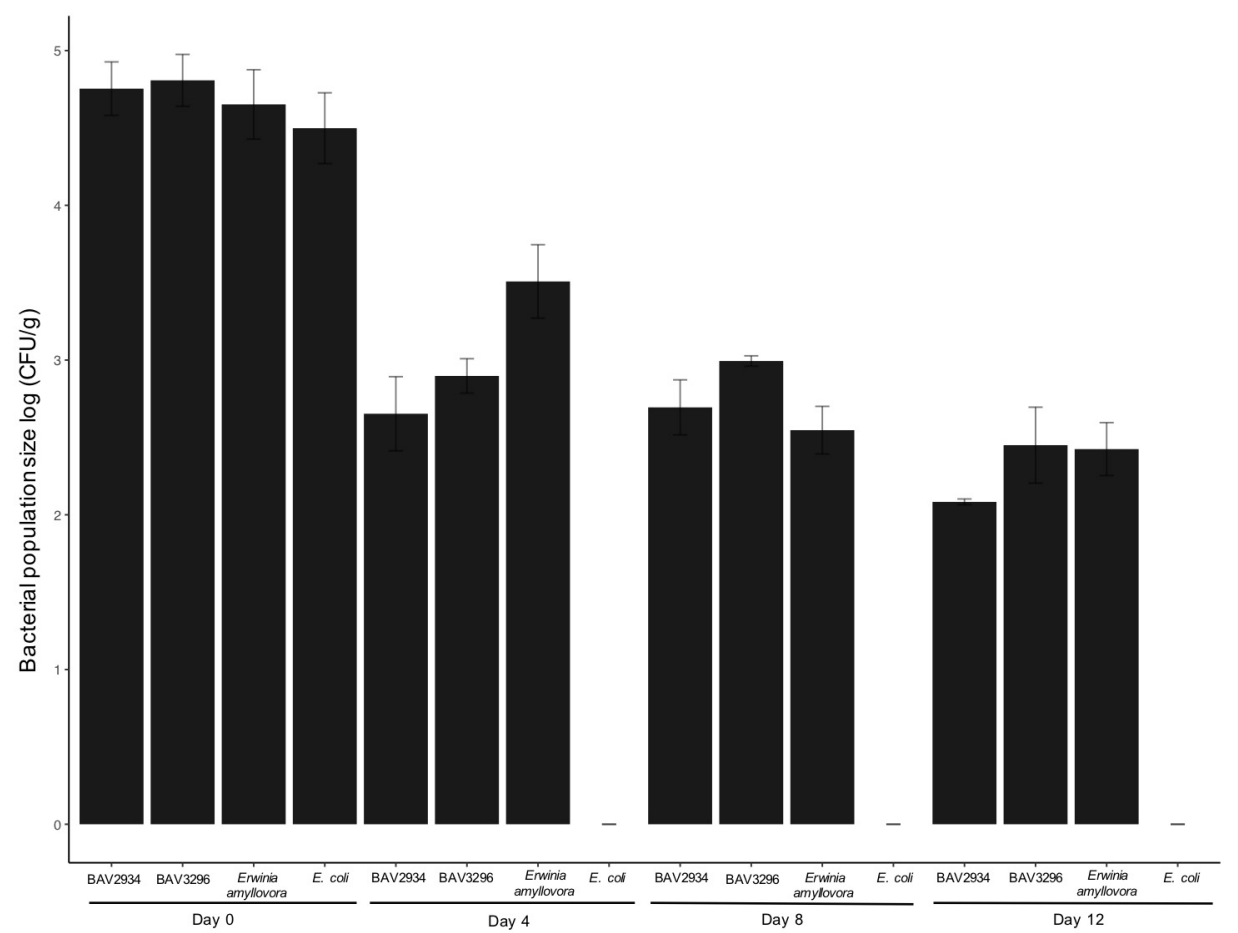

FIGURE 1 | Inhibitory activity of rain-isolated bacteria against $E$. amylovora represented by (A) example of the halo inhibition assay showing the inhibition zone produced by strain BAV3296, (B) average size of the inhibition zone induced by strains BAV2934 and BAV3296, and (C) survival, measured as population size, of strains BAV2934 and BAV3296 compared with E. amylovora on detached apple branches under environmental conditions for up to 12 days. An Escherichia coli strain was included as control.

additional bacterial, fungal, and oomycete plant pathogens. BAV2934 and BAV3296 showed strong activity against the majority of the tested bacterial plant pathogens (including species of Xanthomonas, Pseudomonas, and Ralstonia), but not against fungal and oomycete pathogens, while the Pseudomonas strains BAV3226 and BAV3280 were most effective against fungal and 
TABLE 1 | Identity of nine rain-isolated bacteria that showed antagonistic activity against E. amylovora in the initial inhibition screen.

\begin{tabular}{|c|c|c|c|c|c|}
\hline Isolate & Source of isolation & Date of isolation & Location of rain collection & 16S rRNA accession number & 16S rRNA-based affiliation \\
\hline BAV 2493 & Rain & $3 / 12 / 13$ & Private home, Blacksburg, VA, United States & KC901542.1 & Pseudomonas sp. \\
\hline BAV 2502 & Rain & $3 / 13 / 13$ & Private home, Blacksburg, VA, United States & KF956697.1 & Bacillus sp. \\
\hline BAV 2572 & Rain & $4 / 22 / 13$ & Kentland Farm, Blacksburg, VA, United States & $\mathrm{NA}^{1}$ & Pseudomonas sp. \\
\hline BAV 2934 & Rain & $5 / 15 / 13$ & Kentland Farm, Blacksburg, VA, United States & KT580675.1 & Pantoea sp. \\
\hline BAV 3049 & Rain & $6 / 26 / 13$ & Kentland Farm, Blacksburg, VA, United States & JX566609.1 & Pantoea sp. \\
\hline BAV 3226 & Rain & $9 / 26 / 13$ & Latham Hall, Blacksburg, VA, United States & KJ831070.1 & Pseudomonas sp. \\
\hline BAV 3280 & Rain & $9 / 28 / 13$ & Latham Hall, Blacksburg, VA, United States & NA & Pseudomonas sp. \\
\hline BAV 3296 & Rain & $9 / 29 / 13$ & Latham Hall, Blacksburg, VA, United States & KR296701.1 & Pantoea ananatis \\
\hline BAV 4579 & Rain & $3 / 10 / 13$ & Private home, Blacksburg, VA, United States & KC901542.1 & Pseudomonas sp. \\
\hline
\end{tabular}

${ }^{1}$ These strains were identified based on the presence of a Pseudomonas-specific PCR product.

oomycete pathogens (see a summary in Table 2 and quantitative results in Supplementary Table S2).

\section{Rain-Borne Bacteria Colonize and Survive Apple Trees Similar to E. amylovora}

Survival, measured as bacterial population size over time, of Pantoea strains BAV2934 and BAV3296 and rifampicin-resistant E. amylovora BAV5616 was determined on detached apple branches placed on the top of our 3-story research building in three independent experiments performed on the following dates: from November 18th to 30th, 2016, from February 13th to 25th, 2017, and from March 24th to April 5th, 2017. Minimum and maximum temperatures during the three experiments ranged from -6 to $18^{\circ} \mathrm{C},-7$ to $18^{\circ} \mathrm{C}, 0$ to $19^{\circ} \mathrm{C}$, respectively. Apple branches in November 2016 and March 2017 were exposed to rain and light snow (details on weather conditions during the experiments are reported in Supplementary Table S3). Results for the experiment performed in February 2017 are shown in Figure 1C and results for experiments in November 2016 and March 2017 are shown in Supplementary Figure S1. In all three experiments, survival of BAV2934 and BAV3296 was comparable to E. amylovora after 12 days under environmental conditions ( $p$-value 0.0001 ANOVA, Tukey HDS). The main difference between experiments was that in March 2017 the bacterial population size remained the same after 4 days post-inoculation, in contrast to the other two experiments in which the bacterial population size decreased 2-fold by day 4 post-inoculation.

Population size of BAV2934 was also evaluated on apple blossoms at Kentland Farm in spring 2018 at 0, 5, and 10 days post-inoculation (April 25, April 30, and May 5 of 2018). Minimum and maximum temperatures during this experiment ranged from 0 to $27^{\circ} \mathrm{C}$ (Supplementary Table S4). In this case, the total bacterial population size was analyzed in combination with the relative abundance of BAV2934, as determined by culture-independent microbiome analysis. The total culturable bacterial population size on blossoms inoculated with BAV2934 was three-fold higher at 0, 5 and, 10 days post-inoculation, compared to the non-inoculated controls (Figure 2A). The relative abundance of BAV2934 was 95 and $85 \%$ at 5 days and 10 days post-inoculation, respectively, (Figure 2B).

\section{Rain-Borne Bacteria Control Fire Blight on Detached Apple Blossoms}

Fire blight disease severity measured as a fraction of the length of necrosis along the pedicel divided the total pedicel length was significantly reduced by pre-treatments of blossoms with either BAV2934 (approximately 20\% of necrotic pedicel) or BAV3296 (approximately 10\% of necrotic pedicel), as compared to $E$. coli (60\% of necrotic pedicel) and the MgSO 4 mock treatment negative control (70\% of necrotic pedicel) ( $p$-value 0.0001, ANOVA, Tukey HDS). Treatments with the commercial products BlightBan ${ }^{\mathrm{TM}}$ A506 (approximately 10\% of necrotic pedicel) and FireWall ${ }^{\mathrm{TM}}$ (approximately $5 \%$ of necrotic pedicel) were similarly effective with disease being less severe than the mock treatment for both of them (Figure 3A).

Erwinia amylovora population size in the receptacle and the pedicel was also significantly reduced by pre-treatment with either BAV2934 or BAV3296, compared to E. coli and $\mathrm{MgSO}_{4}$ ( $p$-value 0.0001 ANOVA, Tukey HDS). In the receptacle, for example, the E. amylovora population was reduced by over 2fold on blossoms treated with BAV2934 and BAV3296, compared to blossoms treated with E. coli or $\mathrm{MgSO}_{4}$ ( $p$-value 0.0001 ANOVA, Tukey HDS). Similar pathogen population sizes were found in the receptacles of blossoms treated with BlightBan ${ }^{\mathrm{TM}}$. However, BlightBan ${ }^{\mathrm{TM}}$ was not as effective as FireWall ${ }^{\mathrm{TM}}$, which suppressed pathogen growth almost completely (Figure 3B). In the pedicel, the effect of BAV2934 or BAV3296 was similar to BlightBan $^{\mathrm{TM}}$, in terms of E. amylovora population reduction. FireWall $^{\mathrm{TM}}$ again provided the most protection (Figure $3 \mathrm{C}$ ).

\section{Rain-Borne Bacteria Show Inconsistent Results in Controlling Fire Blight in an Apple Orchard}

Disease incidence of E. amylovora-inoculated apple blossoms pre-treated with BAV2934 and BAV3296 was compared with disease incidence following pre-treatments with commercial products BlightBan ${ }^{\mathrm{TM}} \mathrm{A} 506$ and FireWall $^{\mathrm{TM}}$ or a mock treatment negative control $\left(10 \mathrm{mM} \mathrm{MgSO}_{4}\right)$ in spring 2018 and spring 2019. Disease incidence was calculated as percentage 
TABLE 2 | Inhibition assay of rain-isolated bacteria against bacterial, fungal and oomycete plant pathogens (Part 1)

\begin{tabular}{|c|c|c|c|c|c|c|c|c|c|}
\hline \multicolumn{2}{|c|}{ Rain isolatedbacteria } & \multirow{2}{*}{$\begin{array}{c}\text { Xanthomonas } \\
\text { sp. } \\
-\end{array}$} & \multirow{2}{*}{$\begin{array}{c}\begin{array}{c}\text { Xanthomonas } \\
\text { sp. }\end{array} \\
++\end{array}$} & \multirow{2}{*}{$\begin{array}{c}\begin{array}{c}\text { Pto } \\
\text { DC3000 }\end{array} \\
-\end{array}$} & \multirow{2}{*}{$\begin{array}{c}\text { Pto } \\
\text { K40 } \\
-\end{array}$} & \multirow{2}{*}{$\begin{array}{c}\begin{array}{c}\text { Pma } \\
\text { ES4326 }\end{array} \\
-\end{array}$} & \multirow{2}{*}{$\begin{array}{c}\text { A. citrulli } \\
\text { AAC00-1 } \\
+\end{array}$} & \multirow{2}{*}{$\begin{array}{c}\begin{array}{c}\text { Robbsia } \\
\text { andropogonis }\end{array} \\
--\end{array}$} & \multirow{2}{*}{$\begin{array}{c}\text { A. tumefaciens } \\
++\end{array}$} \\
\hline BAV2493 & Pseudomonas sp. & & & & & & & & \\
\hline BAV2502 & Bacillus sp. & - & - & - & - & ++ & + & + & ++ \\
\hline BAV2572 & Pseudomonas sp. & + & + & + & + & + & - & - & + \\
\hline BAV2934 & P. agglomerans & + & ++ & + & + & + & - & + & + \\
\hline BAV3049 & Pantoea sp. & - & - & - & - & ++ & + & + & +++ \\
\hline BAV3226 & Pseudomonas sp. & +++ & +++ & ++ & ++ & ++ & +++ & +++ & +++ \\
\hline BAV3280 & Pseudomonas sp. & +++ & + & ++ & ++ & ++ & ++ & ++ & + \\
\hline BAV3296 & Pantoea ananatis. & +++ & +++ & ++ & + & ++ & ++ & +++ & +++ \\
\hline BAV4579 & Pseudomonas sp. & + & + & - & - & - & + & - & ++ \\
\hline
\end{tabular}

TABLE 2 | Inhibition assay of rain-isolated bacteria against bacterial, fungal and oomycete plant pathogens (Part 2)

\begin{tabular}{|c|c|c|c|c|c|c|c|}
\hline \multicolumn{2}{|c|}{ Rain isolatedbacteria } & \multirow{2}{*}{$\begin{array}{c}\text { Phytophthora } \\
\text { capsici }\end{array}$} & \multirow{2}{*}{$\begin{array}{c}\begin{array}{c}\text { Botrytis } \\
\text { cinerea } 132\end{array} \\
--\end{array}$} & \multirow{2}{*}{$\begin{array}{c}\begin{array}{c}\text { Botrytis } \\
\text { cinerea } 156\end{array} \\
--\end{array}$} & \multirow{2}{*}{$\begin{array}{c}\begin{array}{c}\text { Botrytis } \\
\text { cinerea 110/P6 }\end{array} \\
-\end{array}$} & \multirow{2}{*}{$\begin{array}{c}\text { Colletotrichum } \\
\text { acetatum C15 }\end{array}$} & \multirow{2}{*}{$\begin{array}{c}\begin{array}{c}\text { Colletotrichum } \\
\text { sp. C2 }\end{array} \\
--\end{array}$} \\
\hline BAV2493 & Pseudomonas sp. & & & & & & \\
\hline BAV2502 & Bacillus sp. & - & - & - & - & - & - \\
\hline BAV2572 & Pseudomonas sp. & + & - & - & - & - & - \\
\hline BAV2934 & P. agglomerans & - & - & - & - & - & - \\
\hline BAV3049 & Pantoea sp. & - & - & - & - & - & - \\
\hline BAV3226 & Pseudomonas sp. & +++ & +++ & +++ & ++ & ++ & ++ \\
\hline BAV3280 & Pseudomonas sp. & +++ & +++ & +++ & ++ & ++ & ++ \\
\hline BAV3296 & Pantoea ananatis. & - & - & - & - & - & - \\
\hline BAV4579 & Pseudomonas sp. & ++ & - & - & - & - & - \\
\hline
\end{tabular}

$+=$ halo inhibition from $0.1-5 \mathrm{~mm},++=$ halo inhibition from $5.5-10 \mathrm{~mm},+++=$ halo inhibition $>10 \mathrm{~mm}$ 
of blossom clusters with fire blight symptoms out of the total number of clusters used in each treatment.

In 2018 on "Golden Delicious," FireWall ${ }^{\mathrm{TM}}$ was the most effective treatment with only $11 \%$ of treated clusters developing disease, while the mock treatment showed $89 \%$ disease incidence ( $p$-value 0.0028 ANOVA, Tukey HDS). No significant differences were observed between BAV2934 with $48 \%$, BlightBan ${ }^{\mathrm{TM}}$ with $63 \%$, and BAV3296 with $70 \%$ disease incidence, compared to the mock treatment (Figure 4A and Supplementary Table S5).

On 'York', the mock treatment showed $76.5 \%$ disease incidence. FireWall ${ }^{\mathrm{TM}}$ and BAV2934 had 0 and $11.5 \%$ disease incidence, respectively, both significantly lower compared to the mock treatment and compared to BlightBan ${ }^{\mathrm{TM}}$ with $55.5 \%$ disease incidence ( $p$-value 0.0016 ANOVA, Tukey HDS). Also BAV3296 with $32.5 \%$ disease incidence showed significant control compared to the mock treatment, but not compared to BlightBan ${ }^{\mathrm{TM}}$. No significant difference was observed between BlightBan ${ }^{\mathrm{TM}}$ and the mock treatment (Figure 4B and Supplementary Table S5).

In 2019, apple blossoms of the varieties "Golden Delicious," "Empire" and "Rome" were pre-treated as in 2018, but one of the BAV2934 UV-generated mutants that had shown no inhibitory activity in vitro was also included. On "Golden Delicious," although no significant differences were observed among pre-treatments ( $p$-value 0.3152 ANOVA, Tukey HDS), FireWall ${ }^{\mathrm{TM}}$ was the best inhibitor of fire blight with 30\% disease incidence. It was followed by BAV2934 with 55\%, the BAV2934 mutant with 65\%, BAV3296 with $70 \%$, and BlightBan ${ }^{\mathrm{TM}}$ with $80 \%$ disease incidence. The mock treatment gave $80 \%$ disease incidence (Figure 4C and Supplementary Table S5).

On "Rome," blossoms pre-treated with BAV3296 had 15\% disease incidence, while the FireWall ${ }^{\mathrm{TM}}$ and BAV2934 UVmutant pre-treatment each had $20 \%$ disease incidence. These pre-treatments were significantly different compared to the pre-treatment with BlightBan ${ }^{\mathrm{TM}}$, which showed $65 \%$ disease incidence, and with the mock treatment, which showed $70 \%$ disease incidence ( $p$-value 0.0083 ANOVA, Tukey HDS). The BAV2934 treatment with $35 \%$ disease incidence was not significantly lower than the mock treatment (Figure 4D and Supplementary Table S5).

On "Empire," the mock treatment showed only $50 \%$ disease incidence. FireWall ${ }^{\mathrm{TM}}$ showed $37 \%$ disease incidence, followed by the BAV2934 mutant with 43\%, BAV2934 with 47\%, BAV3296 with $53 \%$ disease incidence. BlightBan ${ }^{\mathrm{TM}}$ had $80 \%$ disease incidence, which was higher than the mock treatment negative control (Figure 4E and Supplementary Table S5). None of the treatments were significantly different compared to mock ( $p$ value 0.4420 ANOVA, Tukey HDS).

In summary, BAV2934 and BAV3296 reduced disease incidence compared to a mock treatment in four out of five field experiments and this reduction was significant in two of the experiments for BAV3296 and in one experiment for BAV2934. For most field experiments, the reduction in disease incidence by BAV2934 and BAV3296 was similar to BlightBan $^{\mathrm{TM}}$ but not as good as FireWall ${ }^{\mathrm{TM}}$. The BAV2934 UVmutant showed inconsistent control and was not significantly different from the BAV2934 wild-type strain in any of the trials (Supplementary Table S5).

\section{Whole Genome Sequencing Precisely Identified Rain-Borne Bacteria}

The genomes of BAV2934 and BAV3296 were sequenced using Illumina HiSeq technology and assembled. Since NCBI does not provide strain identification using genome sequences as query, we used the "Identify using a genome sequence" function at the LINbase web service at linbase.org. LINbase identifies strains as members of genome similarity groups, such as species and intraspecific taxa, based on average nucleotide identity (ANI) (Tian et al., 2019). BAV2934 was identified as Pantoea agglomerans and BAV3296 as P. ananatis. For BAV2934, we also generated $27 \mathrm{~Gb}$ of long reads using the Oxford Nanopore Technologies MinION ${ }^{\mathrm{TM}}$ sequencer and carried out a hybrid genome assembly of both the short Illumina and long MinION ${ }^{\mathrm{TM}}$ reads, which allowed us to obtain a closed genome of 4,003,977 bp and four circular contigs of 528,933 bp, 205,248 bp, 203,868 bp, and 2,968 bp, respectively. These four contigs probably represent plasmids. Genome sequences were submitted to GenBank with accession numbers GCA_009765475.1 (BAV2934) and GCA_009765415.1 (BAV3296).

\section{A Combination of Biosynthetic Gene Clusters (BGCs) Prediction and UV-Mutagenesis Identified the Genetic Basis of Antibiosis in $P$. agglomerans BAV2934}

To identify putative genes at the basis of the inhibitory activity of BAV2934 against E. amylovora, the genome was annotated using Prokka (Seemann, 2014) and biosynthetic gene clusters (BGCs) were predicted using antiSMASH (Medema et al., 2011) (Supplementary Table S6). Eight BGCs were identified that range from 11,391 to $59,810 \mathrm{bp}$ and were predicted to produce a series of different products (Table 3). To identify if any BGC was involved in the inhibitory activity, a UV-mutant screen was performed in parallel. After UV treatment, 1099 colonies of BAV2934 were screened for loss of inhibition in vitro and five mutants were identified. DNA of the five mutants was pooled and sequenced on the Illumina platform. 21,742,895 reads of a total length of $7.3 \mathrm{~Gb}$ were obtained and mapped against the annotated BAV2934 genome to identify non-synonyms mutations that could explain the loss of the inhibitory activity. Supplementary Table S6 lists the 17 non-synonymous mutations that were found. Gene NOOGOKNH_04505, annotated as a dimodular nonribosomal peptide synthase, was one of them. Using BLAST, it was identified as part of a phenazine antibiotic D-alanylgriseoluteic acid synthesis gene cluster in Erwinia herbicola Eh1087 (Giddens et al., 2002). Among the BGCs predicted in BAV2934 by antiSMASH (Table 3), a phenazine gene cluster was identified in contig 4 , and although not in this BGC, the mutation was $1,843 \mathrm{bp}$ downstream of the phenazine cluster (Supplementary Figure S3) and may contribute to production of the compound. This mutation was confirmed by PCR and Sanger sequencing in one of the five mutants; the gene could not be amplified from 


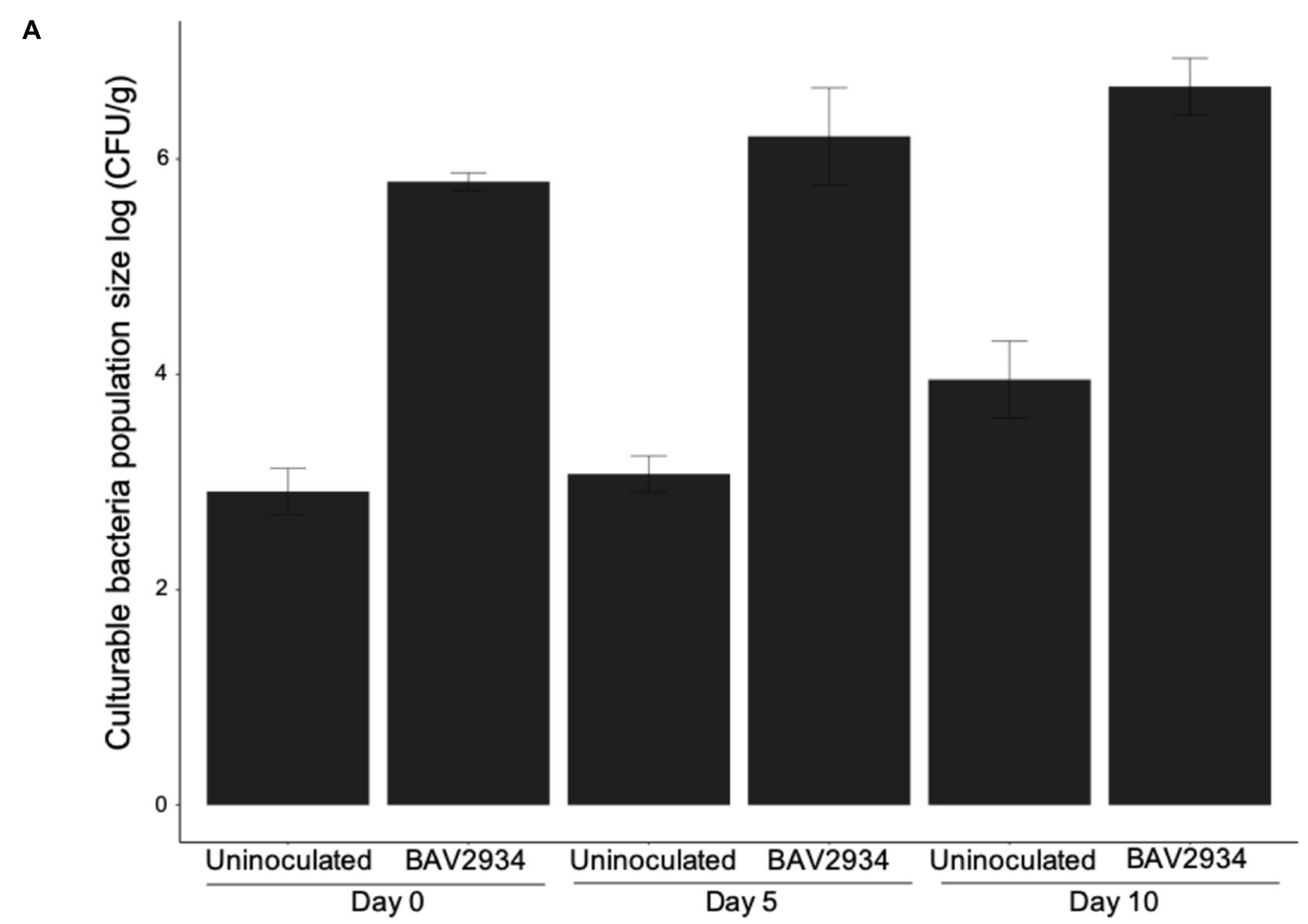

B

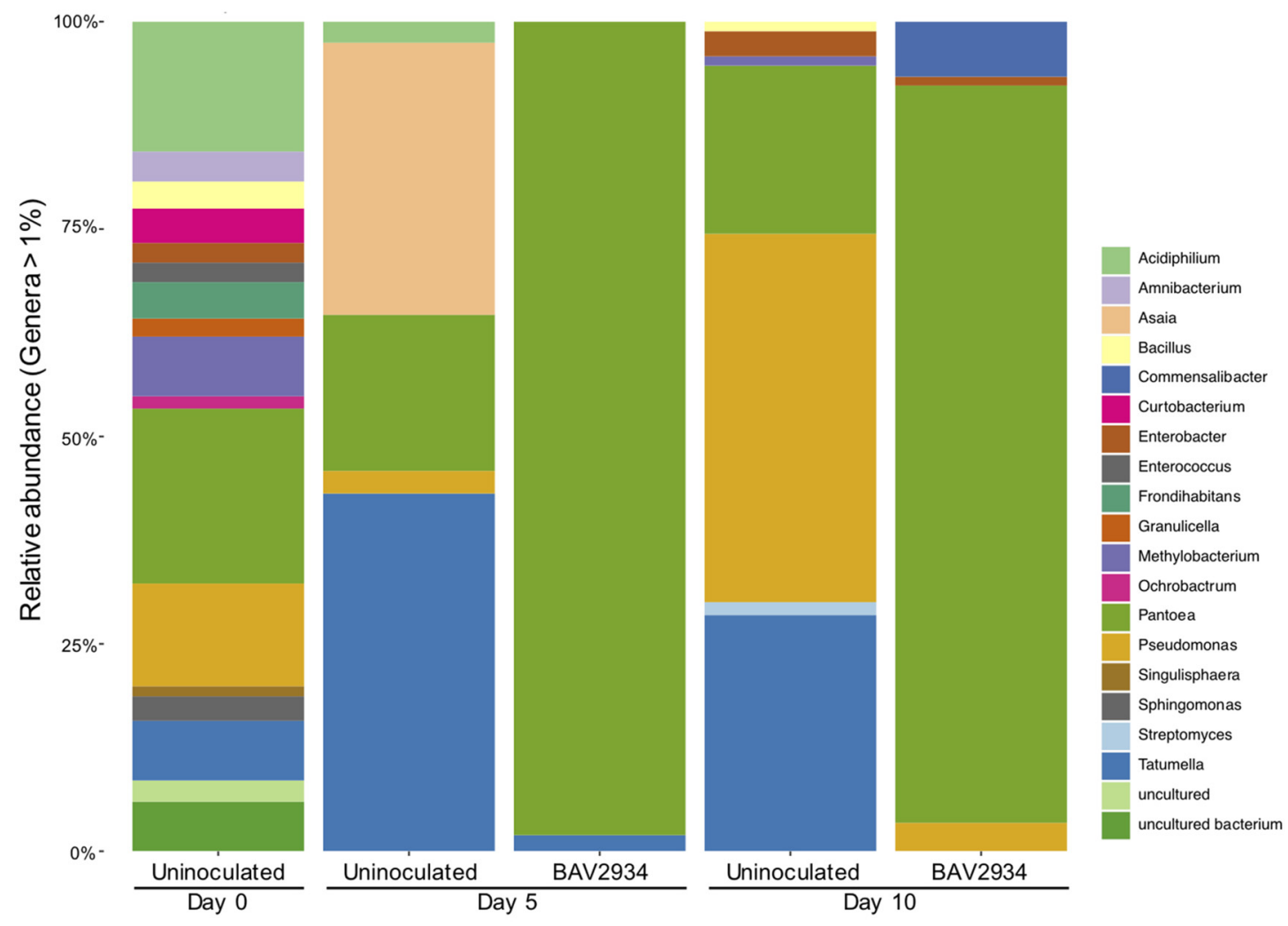

FIGURE 2 | Survival of rain-isolated P. agglomerans BAV2934 on apple blossoms in an orchard. (A) Culturable bacteria, and (B) Relative abundance of bacterial taxa at the genus level (16S rRNA gene) present in blossoms up to 10 days after inoculation with BAV2934. 


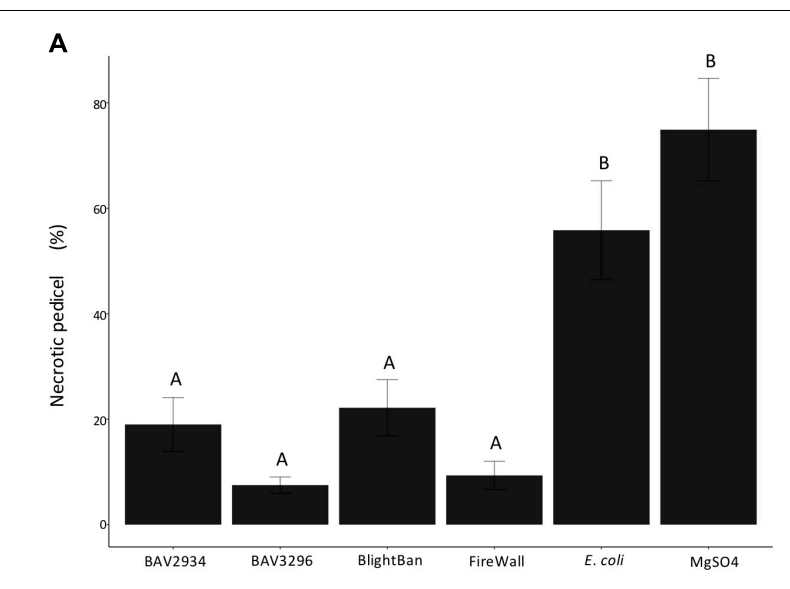

B

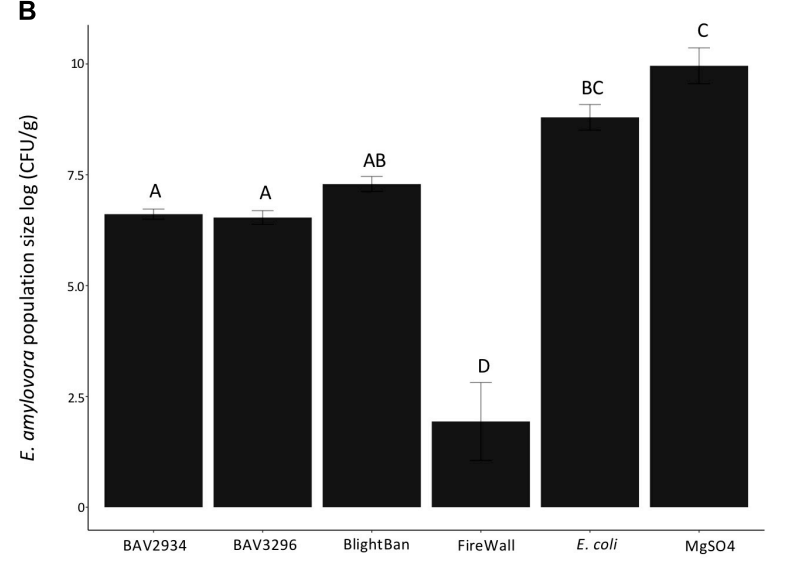

C

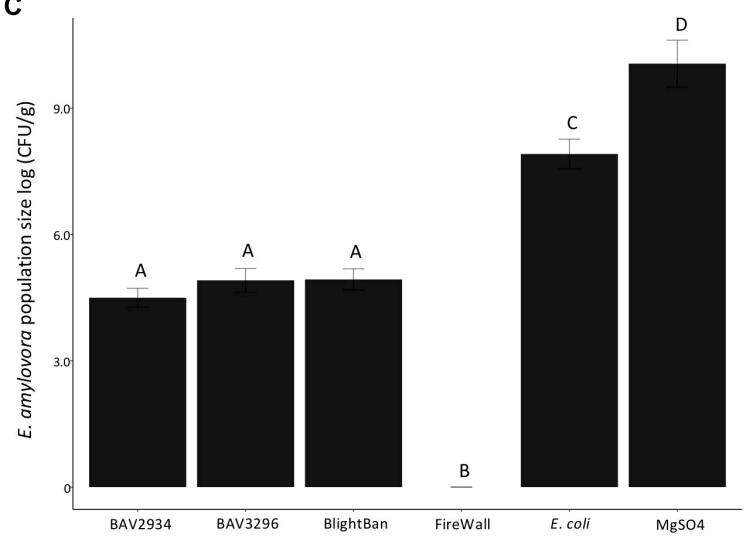

FIGURE 3 | Antagonistic effect of rain-isolated bacteria BAV2934 and BAV3296 against $E$. amylovora on detached blossoms under laboratory conditions. (A) Disease severity measured by the necrotic tissue caused by E. amylovora invasion on the pedicel, (B) Pathogen population size in the receptacle, and $\mathbf{( C )}$ Pathogen population size in the pedicel 7 days after pre-treatment with either rain-isolated bacteria or commercial products.

the other four mutants. Since, based on genome sequencing, the NOOGOKNH_04505 gene is located on the 203,868 bplong contig in the BAV2934 genome assembly, the lack of amplification may have been due to plasmid loss. In fact, genome coverage data of the reads derived from the sequencing of the five mutant-pool showed that the entire contig was present in the pool only at $1 / 4$ th of the average coverage of the main chromosome and PCR with gene-specific primers of chromosomal genes and putative plasmid-encoded genes confirmed the absence of the 203,868 bp-long plasmid in these four mutants (Supplementary Figure S2).

\section{DISCUSSION}

Efficacy of BCAs in the field, in particular when applied to aerial plant surfaces, is dependent on weather conditions during and after application because BCAs need to colonize and survive on plants surfaces in order to efficiently inhibit pathogens (Johnson et al., 2000). In this study, we hypothesized that precipitation may be a promising source of BCAs for aerial plant surfaces, in particular against the fire blight pathogen E. amylovora on apple blossoms, since bacteria that are ubiquitous in the atmosphere and precipitation (Polymenakou, 2012) can be expected to be adapted to some of the same environmental stresses to which BCAs are exposed, such as dramatic changes in temperature, humidity, and UV radiation (Lindow, 1991). Additionally, as part of a separate study (Failor et al., 2017), we had isolated bacteria from rain that were members of the genera Pseudomonas, Pantoea, and Bacillus, which include common plant-associated species, some of which are already used in commercial BCAs (Matyjaszczyk, 2015).

As a first step, we screened 254 rain-isolated bacteria for inhibition of E. amylovora in vitro. We excluded bacteria with confirmed ice nucleation activity from this screen because they could worsen frost damage when used during weather conditions favorable for frost formation (Lindow, 1983). Nine out of the 254 tested bacteria (3.5\%) showed a measurable inhibitory effect against E. amylovora. Two isolates, identified as members of the genus Pantoea, maintained their efficacy against $E$. amylovora even when pathogen concentrations were increased, while the other isolates failed under these conditions. Our use of precipitation as a source of potential BCAs is unconventional, as traditionally plant surfaces and soil are the most commonly utilized sources for BCAs isolation. Gerami et al. (2013) found that almost 50\% of 120 tested epiphytic bacterial strains, isolated from blossoms, leaves and shoots of pome-fruit and stone-fruit trees, inhibited E. amylovora in vitro but only 4 isolates worked efficiently in both in vitro and in planta assays. Sharifazizi et al. (2017) found that $45 \%$ of 22 pear leaf-associated bacterial isolates inhibited E. amylovora in vitro. It is challenging to compare our success rate with rain-isolated bacteria with the success rate in these screens using epiphytic bacteria since many factors contribute to the efficiency of bacteria to inhibit pathogens in vitro, including: the identity of the pathogen strain, the concentration at which potential BCAs and pathogens are plated, and the type of growth medium used (Dickie and Bell, 1995; Borowicz and Saad Omer, 2000). Therefore, in the absence of a direct comparison with other isolation sources, we cannot conclude if rain harbors a higher or lower proportion of bacteria that effectively inhibit pathogens in vitro compared to bacteria isolated from other sources. Nonetheless, since we 
A

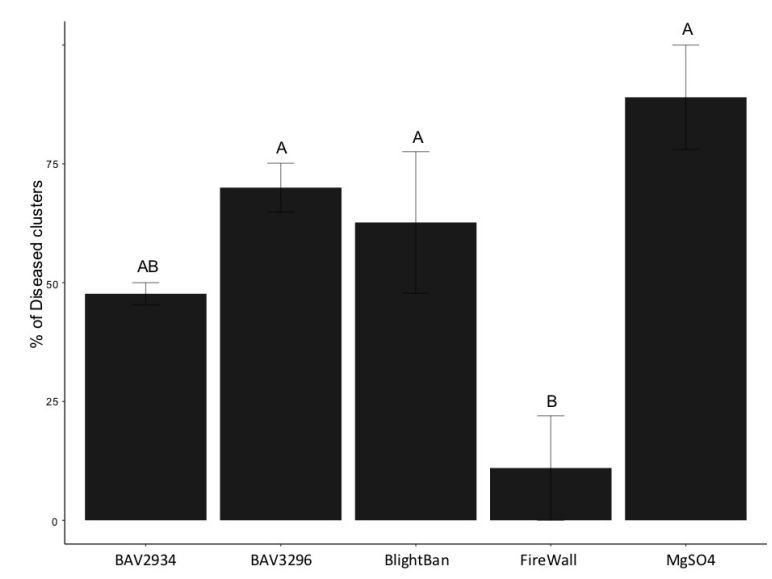

C

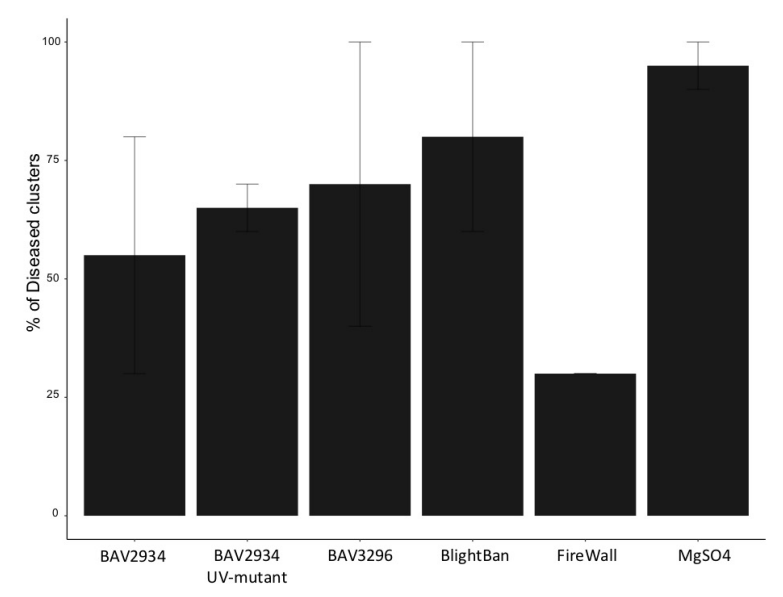

B

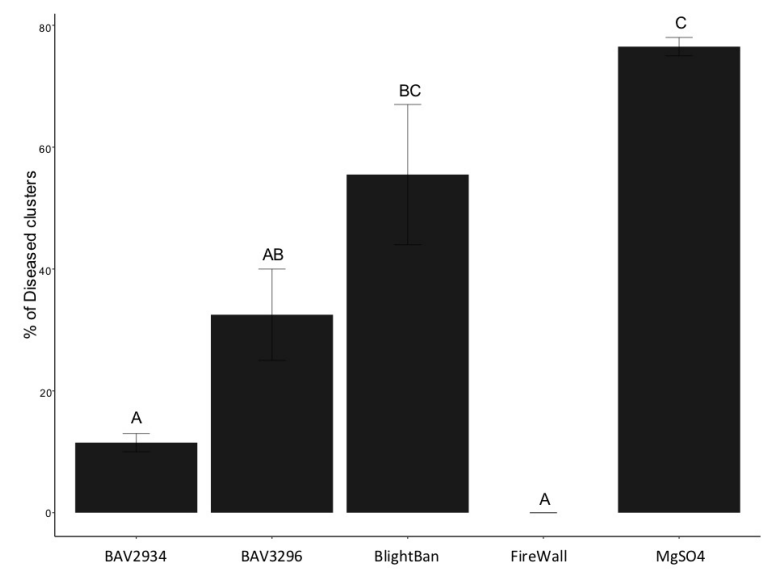

D

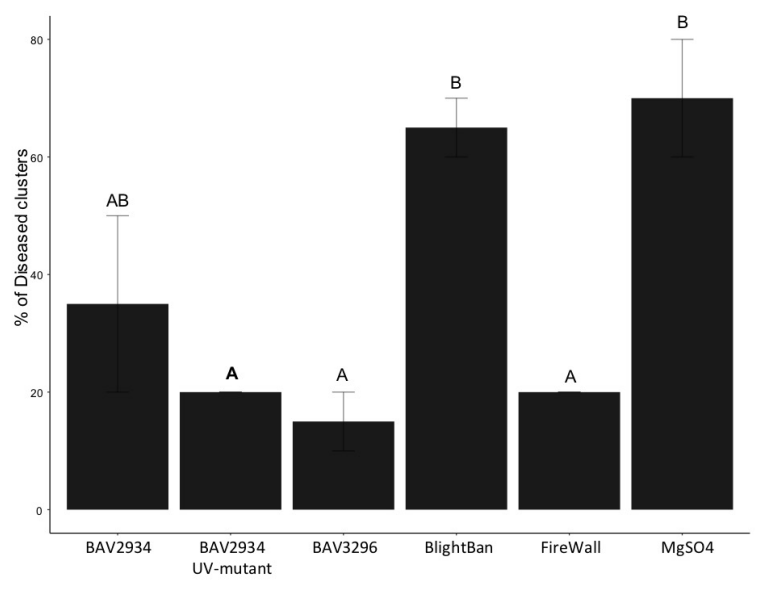

E

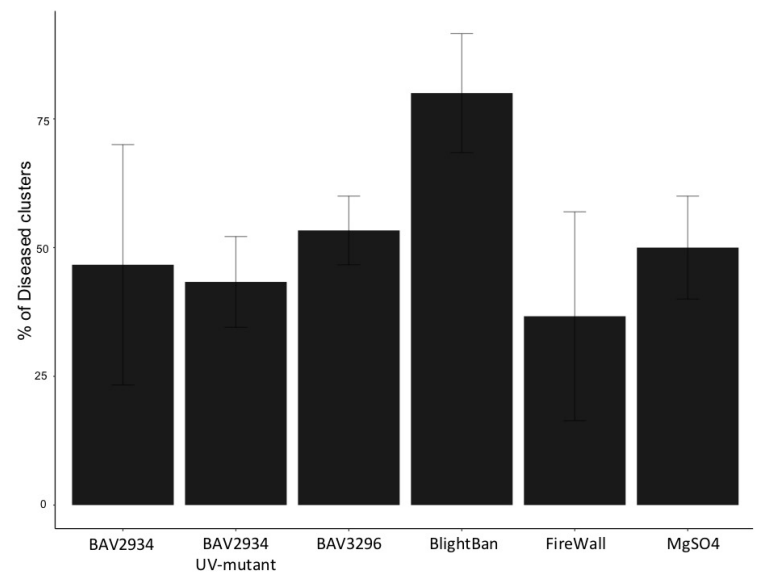

FIGURE 4 | Fire blight control on blossoms in an apple orchard. (A) Disease incidence on "Golden Delicious" in 2018, (B) Disease incidence on "York" in 2018, (C) Disease incidence on "Golden Delicious" in 2019, (D) Disease incidence on "Rome" in 2019, (E) Disease incidence on "Empire" in 2019. 
TABLE 3 | Biosynthetic gene clusters predicted in BAV2934 (GCA_009765475.1) by antiSMASH (Medema et al., 2011).

\begin{tabular}{|c|c|c|c|c|c|}
\hline Contig & Predicted product & BGC coordinates & BGC size & Most similar known cluster & Similarity \\
\hline 1 & $\begin{array}{l}\text { Arylpolyene, } \\
\text { Homoserine lactone }\end{array}$ & $2,541,579-2,601,389$ & 59,810 & APE Ec & $78 \%$ \\
\hline 1 & Thiopeptide & $2,667,346-2,693,602$ & 26,256 & O-antigen & $14 \%$ \\
\hline 1 & Homoserine lactone & $3,464,471-3,485,109$ & 20,638 & - & \\
\hline 1 & NRPS & $3,575,053-3,627,116$ & 52,063 & Amonabactin & $57 \%$ \\
\hline 2 & Siderophore & $158,889-171,243$ & 12,354 & Desferrioxamine & $100 \%$ \\
\hline 2 & Terpene & $345,771-369,332$ & 23,561 & Carotenoid & $100 \%$ \\
\hline 3 & Bacteriocin & $104,879-116,270$ & 11,391 & - & \\
\hline 4 & Phenazine & 78,916-99,392 & 20,476 & Pyocyanine & $57 \%$ \\
\hline
\end{tabular}

succeeded in identifying two Pantoea isolates that strongly inhibited E. amylovora in vitro, further tests to determine their survival rate and their efficiency in vivo were warranted.

Since the main motivation behind our study was the expectation that rain-isolated bacteria could persist on plant surfaces despite environmental stresses, we tested survival on both apple branches and blossoms. On apple branches, the rainisolated strains BAV2934 and BAV3296 showed a very similar survival rate to E. amylovora declining approximately 100 -fold after 12 days post-inoculation in three separate experiments in November, February, and March, while E. coli was already undetectable 4 days post-inoculation. The decline was faster in November and February probably due to colder temperatures, compared to those recorded in March (Supplementary Table S3). Although we did not extend survival assays beyond 12 days, the fact that survival of BAV2934 and BAV3296 was similar to survival of E. amylovora on apple branches gives confidence that rain-borne bacteria are able to persist on plant surfaces as we had hypothesized. This result also suggests that winter and spring applications of these potential BCAs should be tested, to determine if such applications could reduce fire blight incidence in the following spring and summer.

When testing survival on apple blossoms, the total bacterial population size on blossoms inoculated with BAV2934 was significantly larger than the population size on non-inoculated blossoms 10 days post-inoculation (Figure 2A). Further, the relative abundance of BAV2934 remained stable, representing over $85 \%$ of the total population at 10 days post-inoculation (Figure 2B). This evidence also suggests that BAV2934 is able to robustly colonize and persist on healthy apple blossoms under field conditions. In contrast, Wei et al. (2016) found that the relative abundance of a potential BCA (Bacillus subtilis) in strawberry leaves was found to be depleted by $50 \% 8$ days post-inoculation under field conditions. Another study found the population size of a potential Lactobacillus plantarum BCA decreased significantly 10 days after inoculation on kiwifruit, strawberry, and Prunus leaves, even under stable greenhouse conditions (Daranas et al., 2019). When compared to those BCAs, which were isolated from plants or soil, our rain-borne isolate BAV2934 demonstrated better survival on aerial plant surfaces. However, since differences in bacterial survival rate depend on the type of plant surface (Pujol et al., 2006; Bonaterra et al., 2007) and environmental conditions (Nuclo et al., 1998), we cannot make general conclusions before testing our rain-isolated bacteria in different geographic locations.
Some BCAs have a broad spectrum of inhibition against many plant pathogens (Ishimaru et al., 1988; Mora et al., 2015; Daranas et al., 2019). Here, we observed that our initial 9 rain-isolated bacteria have the ability to suppress a wide range of bacterial, fungal, and oomycetes pathogens in vitro (Supplementary Table S2). However, the efficacy of the rainisolated Pantoea and Bacillus strains was limited to bacterial pathogens. In contrast, the Pseudomonas isolates inhibited bacterial, fungal, and oomycete plant pathogens. This suggests either the production of several antimicrobial compounds (Bender et al., 1999) in these strains or the production of an antibiotic with broad spectrum activity (Ishimaru et al., 1988). The broad spectrum activity against fungi and bacteria observed in the rain-isolated Pseudomonas strain agrees with previous reports that Pseudomonas isolates produce siderophores with antimicrobial properties in disease-suppressive soils (Kloepper et al., 1980). For example, P. fluorescens strain UP61 produces three different antibiotics, including pyrrolnitrin, pyoluteorin and 2,4-diacetylphloroglucinol, involved in the inhibition of fungal, oomycete and bacterial plant pathogen strains (La Fuente et al., 2004). Also, several Pseudomonas syringae strains produce syringomicins and syringopeptins that inhibit a broad spectrum of fungi and bacteria, respectively (Bensaci et al., 2011).

The effect of timing of BCA application compared to pathogen inoculation is variable. While (Wilson et al., 1992a) reported a significant control of $E$. amylovora on hawthorn blossoms when biocontrol and pathogen were co-inoculated (Wilson et al., 1992b) found that Pseudomonas fluorescens strain A506 effectively protected pear blossoms when blossoms were inoculated with the BCA in advance, but not when blossoms were co-inoculated with the BCA and E. amylovora. In detached blossom assays, we decided to apply rain-isolated bacteria 2 days before we applied the pathogen to allow sufficient time for blossom colonization by our putative BCAs. In contrast, in the field experiments, BCA treatments were done only $2 \mathrm{~h}$ before E. amylovora inoculation because we wanted to inoculate both the BCA and the pathogen when the blossoms were most susceptible. Also, since E. amylovora can persist in symptomless infected plant tissue (Crepel and Maes, 2000; Weißhaupt et al., 2016), the pathogen can spread and colonize blossoms as soon as they open. Therefore, testing BCAs by applying them only $2 \mathrm{~h}$ before inoculation with the pathogen may represent a more realistic scenario for the use of BCAs in agricultural practice.

In some studies, no relationship was found between in vitro antibiosis and in vivo bacterial performance (Özaktan et al., 1999; 
Gerami et al., 2013). Our rain-isolated bacteria were initially tested for antibiosis in a dual culture assay against E. amylovora (Table 2) with the goal of finding potential new secondary metabolites in further experiments. Then, the best inhibitors of E. amylovora in vitro were tested for their ability to suppress fire blight in planta. Published assays for testing the efficiency of BCAs in controlling fire blight on detached blossoms only rate disease incidence on whole blossoms (Bonaterra et al., 2007; Roselló et al., 2013). We decided to measure the pathogen population size separately in the receptacle and the pedicel and to measure the necrotic portion of the blossom pedicel. Our reasoning for evaluating the pedicel separately from the receptacle was that the ability of a BCA to reduce symptoms and pathogen population size should be a measure of its ability to interfere with pathogen colonization and migration into the rest of the apple tree. Using this experimental setup, we found that strains with the best in vitro performance had in vivo performance similar to the commercial BCA BlightBan ${ }^{\mathrm{TM}}$ A506, but were not as efficient as the streptomycin product FireWall ${ }^{\mathrm{TM}}$.

We observed inconsistent results when the rain-isolated bacteria were inoculated on attached blossoms in an apple orchard (Figure 4). BAV2934 significantly reduced disease incidence compared to the mock treatment in only one out of five trials, while BAV3296 significantly reduced disease incidence in only two out of five trials. In addition, BAV2934 or BAV3296 only performed significantly better than the commercial BCA BlightBan $^{\mathrm{TM}}$ in one trial each. The streptomycin product FireWall $^{\text {TM }}$ generally performed the best in field trials, significantly reducing disease incidence in three out of five trials. We expected the BAV2934 mutant, which had lost activity in the in vitro assays, to perform poorer than the wild-type BAV2934 on attached blossoms, but we could not observe any significant differences between the two. Some of the nonsignificant differences we observed between treatments may have simply been due to small sample sizes (20 to 30 clusters per treatment per trial), but such variability is generally in line with previous studies using other BCAs. For example (Sundin et al., 2009), found that BCA applications were inefficient and highly variable in the control of fire blight in the field in Michigan, New York, and Virginia. However, it is possible that better and more consistent results could have been obtained if BAV2934, BAV3296, and BlightBan ${ }^{\mathrm{TM}}$ had been applied more in advance of pathogen inoculation, allowing BCA organisms more time to colonize the blossoms. BCA variability may also be related to inoculum preparation (Stockwell et al., 1998) showed that lyophilized cells of P. fluorescens A506 and P. agglomerans C9$1 \mathrm{R}$ established better on apple blossoms than inoculum prepared from fresh bacterial cells harvested directly from solid agar medium. Özaktan et al. (1999) tested several formulations of $P$. agglomerans where talc-based formulations showed better control of fire blight on pear blossoms than lyophilized and whey-based treatments. Further adaptive strategies, including osmoadaptation and acidic conditions, have also been tested as means to increase bacterial survival and fire blight control in both controlled laboratory and field conditions (Bonaterra et al., 2007; Daranas et al., 2018). In our study, bacterial cells were harvested from agar medium and used immediately to inoculate apple blossoms in our laboratory and field trials. Therefore, it may be possible to improve the control efficiency of the rain-isolated bacteria by optimizing their formulation. Additional trials in other geographic locations using alternative formulations will be necessary to determine if our rain-isolated BCAs can provide more efficient fire blight control under field conditions than currently available BCA products.

It is possible that temperatures following application and during incubation affected the control demonstrated in the orchard (Figure 4 and Supplementary Table S3). In 2019, control was generally least effective on the cultivar "Empire" and this was true for all biocontrol organisms and by FireWall ${ }^{\mathrm{TM}}$. Postinoculation temperatures were also coolest on this cultivar: $10.9^{\circ} \mathrm{C}$ during the first 8 days after application and $12.6^{\circ} \mathrm{C}$ during the 16-day period until data collection. Control was generally better on cultivars "Golden Delicious" and "Rome" in 2019 , and post-inoculation temperatures for these cultivars were warmer with $16.6^{\circ} \mathrm{C}$ during the first 8 days after application and $17.1^{\circ} \mathrm{C}$ during the 12 -day period until data collection. Despite inconsistent results across cultivars, relative percent control appears to be greater on "Golden Delicious" and "Rome" because fire blight infection on the $\mathrm{MgSO}_{4}$ control was greater under these warmer conditions. However, varietal differences may also be a factor, as control was greater on "Rome" than on "Golden Delicious" although both cultivars were treated and inoculated on the same day in 2019.

Pantoea species have been shown to produce different antibiotic compounds (Wright et al., 2001). In this study we identified a BGC that is predicted to produce a phenazine by $P$. agglomerans isolate BAV2934, and this molecule has been shown to be required for inhibition of E. amylovora in vitro by Giddens et al. (2002). The locus identified by UV mutagenesis is likely to contribute to the phenazine production, since the gene is in close proximity to the predicted BGC, in the same polarity, and because Dimodular NRPS are known to contribute to assist in the production of antibiotics (Felnagle et al., 2008). Phenazines are also produced by many other bacteria including: Pseudomonas spp. (Thomashow and Weller, 1988), Streptomyces spp. (Karnetová et al., 1983), and P. agglomerans (Giddens et al., 2002). However, in our rain-isolated bacteria, which included fluorescent Pseudomonas and Pantoea isolates, we only identified a phenazine cluster gene in BAV2934.

Due to the extensive genetic diversity found within many bacterial species, some species can include both beneficial and pathogenic bacteria. For example, while some $P$. agglomerans strains are commercialized as BCAs, others are known plant pathogens or recognized opportunistic human pathogens, isolated from wounds (Cruz et al., 2007; Lee et al., 2010; Smits et al., 2015). P. ananatis also includes both plant pathogens (De Baere et al., 2004; Coutinho and Venter, 2009) and BCAs (Wu et al., 2016). Unfortunately, it is not well known for either $P$. agglomerans or $P$. ananatis if the same strains can be both beneficial and pathogenic, or if some strains are pathogenic, while others are beneficial. The taxonomy within the Pantoea genus is also rapidly changing, which leads to another complication in that some Pantoea isolates reported as members of a certain Pantoea species have been incorrectly identified (Rezzonico et al., 2009). The LINbase web service (Tian et al., 2019) represents a practical tool to improve precise 
genome-based identification of BCAs, since it allows classification and identification of bacteria at the genus-, species-, and intraspecies ranks. However, precise genome-based prediction of pathogenicity and other phenotypes for strains belonging to a certain species only becomes possible after careful phenotypic characterization of many reference strains within that species. Because this foundational work has not been done yet with either P. agglomerans or P. ananatis, LINbase was useful in identifying BAV2934 and BAV3296 as members of these species, but it was impossible to infer their safety as BCAs.

In summary, we have found that rain serves as a reservoir of bacteria that suppress growth of E. amylovora and other plant pathogens in vitro. Two of the bacteria we isolated were shown to control fire blight on detached blossoms, to survive similarly to E. amylovora on apple branches and blossoms, and, although inconsistently, to control fire blight in the field. Using a combination of genomics and UV-mutagenesis, we also determined the likely mechanism of antibiosis in one of the isolates. While it was straightforward to identify potential BCAs to the species-level using genomics, a database with more thorough phenotypic characterization of strains in regard to pathogenicity on plants and humans will be necessary to infer safety of BCAs based on their genome sequences alone. Therefore, additional field tests, and formulations and safety tests will need to be performed before making a conclusive determination of the potential of the identified rain-borne bacteria as commercial BCAs.

\section{DATA AVAILABILITY STATEMENT}

Genome sequences were submitted to GenBank and were assigned accession numbers GCA_009765475.1 (BAV2934) and GCA_009765415.1 (BAV3296).

\section{AUTHOR CONTRIBUTIONS}

MM conducted most of the experiments with contributions from $\mathrm{VB}$ and $\mathrm{KH}$. LT contributed to the bioinformatics analysis. HW analyzed genomes for prediction of the biosynthetic gene clusters. $\mathrm{BV}, \mathrm{KY}$, and SM developed the overall project. MM and BV wrote the manuscript with input from the other authors.

\section{REFERENCES}

Alamri, S. A. M., Hashem, M., Mostafa, Y. S., Nafady, N. A., and Abo-Elyousr, K. A. M. (2019). Biological control of root rot in lettuce caused by Exserohilum rostratum and Fusarium oxysporum via induction of the defense mechanism. Biol. Control 128, 76-84.

Andrews, S. (2010). FastQC: A Quality Control Tool for High Throughput Sequence Data. Available at: http://www.bioinformatics.babraham.ac.uk/projects/fastqc/ (accessed February 7, 2019).

Bankevich, A., Nurk, S., Antipov, D., Gurevich, A. A., Dvorkin, M., Kulikov, A. S., et al. (2012). SPAdes: a new genome assembly algorithm and its applications to single-cell sequencing. J. Comput. Biol. 19, 455-477. doi: 10.1089/cmb.2012. 0021

\section{FUNDING}

This research was supported by the Virginia Agricultural Council (Project number 671) and, in part, by the National Science Foundation (DEB-1241068 and IOS-1754721). Funding to $\mathrm{BV}$ and $\mathrm{KY}$ was also provided in part by the Virginia Agricultural Experiment Station and the Hatch Program of the National Institute of Food and Agriculture, United States Department of Agriculture.

\section{ACKNOWLEDGMENTS}

The authors are grateful to Ricky Hughes for facilitating the access to the experimental orchard at Kentland Farm, Virginia Tech (Blacksburg, VA, United States).

\section{SUPPLEMENTARY MATERIAL}

The Supplementary Material for this article can be found online at: https://www.frontiersin.org/articles/10.3389/fmicb. 2020.00199/full\#supplementary-material

FIGURE S1 | Bacterial survival rate of rain-isolated BAV2934, BAV3296 and E. amylovora BAV5616 on apple branches under environmental conditions in (A) November 2016 and (B) March 2017 under environmental conditions.

FIGURE S2 | PCR detection of contig 4 in BAV2934. (A) Contig 4 gene NOOGOKNH_04505, (B) Contig 4 gene NOOGOKNH_04435, (C) Contig 4 gene NOOGOKNH_04535, (D) Contig 4 gene NOOGOKNH_04609, (E) Chromosomal gene NOOGOKNH_2217, and (F) Chromosomal gene NOOGOKNH_02219.

FIGURE S3 | Identified BGC predicted to encode a phenazine compound. The red dashed box indicates the gene cluster identified by antiSMASH. The black vertical line indicates the location of the base pair mutation. JGI IMG base pair coordinates are indicated.

TABLE S1 | List of rain-isolated bacteria tested in the initial inhibition assay.

TABLE S2 | Antagonistic activity of rain-isolated bacteria against plant pathogens.

TABLE S3 | Bacterial survival assay on apple branches under environmental conditions.

TABLE S4 | Weather conditions during field treatments at Kentland Farm, VA.

TABLE S5 | Infection (\% infected clusters) and control (\% reduction compared to $\left.\mathrm{MgSO}_{4}\right)$ in the field.

TABLE S6 | BAV2934 UV-generated non-synonyms mutations.

Barrick, J. E. (2014). UV Mutagenesis of Bacteria. Available at: http://barricklab.org/ twiki/bin/view/Lab/ProtocolsUVLibrary (accessed March 14, 2018).

Bender, C. L., Rangaswamy, V., and Loper, J. (1999). Polyketide production by plant-associated Pseudomonads. Annu. Rev. Phytopathol. 37, 175-196.

Bensaci, M. F., Gurnev, P. A., Bezrukov, S. M., and Takemoto, J. Y. (2011). Fungicidal activities and mechanisms of action of Pseudomonas syringae pv. syringae Lipodepsipeptide Syringopeptins 22A and 25A. Front. Microbiol. 2:216. doi: $10.3389 /$ fmicb.2011.00216

Bolger, A. M., Lohse, M., and Usadel, B. (2014). Trimmomatic: a flexible trimmer for illumina sequence data. Bioinformatics 30, 2114-2120. doi: 10.1093/ bioinformatics/btu170

Bonaterra, A., Badosa, E., Cabrefiga, J., Francés, J., and Montesinos, E. (2012). Prospects and limitations of microbial pesticides for control of bacterial and 
fungal pomefruit tree diseases. Trees (Berl. West) 26, 215-226. doi: 10.1007/ s00468-011-0626-y

Bonaterra, A., Cabrefiga, J., Camps, J., and Montesinos, E. (2007). Increasing survival and efficacy of a bacterial biocontrol agent of fire blight of rosaceous plants by means of osmoadaptation. FEMS Microbiol. Ecol. 61, 185-195. doi: 10.1111/j.1574-6941.2007.00313.x

Borowicz, J. J., and Saad Omer, Z. (2000). Influence of rhizobacterial culture media on plant growth and oninhibition of fungal pathogens. BioControl 45, 355-371.

Bushnell, B. (2014). “BBMap: a fast, accurate, splice-aware aligner,". in Proceedings of the 9th Annual Genomics of Energy and Environment Meeting, Walnut Creek, CA.

Büyükcam, A., Tuncer, Ö, Gür, D., Sancak, B., Ceyhan, M., Cengiz, A. B., et al. (2018). Clinical and microbiological characteristics of Pantoea agglomerans infection in children. J. Infect. Public Health 11, 304-309. doi: 10.1016/j.jiph. 2017.07.020

CABI (2018). Invasice Species Compendium. Available at: https://www.cabi.org/ISC (accessed March 13, 2019).

Caporaso, J. G., Kuczynski, J., Stombaugh, J., Bittinger, K., Bushman, F. D., Costello, E. K., et al. (2010). QIIME allows analysis of high-throughput community sequencing data. Nat. Methods 7, 335-336.

Coutinho, T. A., and Venter, S. N. (2009). Pantoea ananatis: an unconventional plant pathogen. Mol. Plant Pathol. 10, 325-335. doi: 10.1111/j.1364-3703.2009. 00542.x

Crepel, C., and Maes, M. (2000). Hibernation of the fire blight pathogen Erwinia amylovora in host plants. Meded. Fac. Landbouwkund. Toegepaste Biol. Wet. (Univ. Gent) 65, 19-25.

Cruz, A. T., Cazacu, A. C., and Allen, C. H. (2007). Pantoea agglomerans, a plant pathogen causing human disease. J. Clin. Microbiol. 45, 1989-1992. doi: 10. 1128/jcm.00632-07

Daranas, N., Badosa, E., Francés, J., Montesinos, E., and Bonaterra, A. (2018). Enhancing water stress tolerance improves fitness in biological control strains of Lactobacillus plantarum in plant environments. PLoS One 13:e0190931. doi: 10.1371/journal.pone.0190931

Daranas, N., Roselló, G., Cabrefiga, J., Donati, I., Francés, J., Badosa, E., et al. (2019). Biological control of bacterial plant diseases with Lactobacillus plantarum strains selected for their broad-spectrum activity. Ann. Appl. Biol. 174, 92-105. doi: 10.1111/aab.12476

De Baere, T., Verhelst, R., Labit, C., Verschraegen, G., Wauters, G., Claeys, G., et al. (2004). Bacteremic infection with Pantoea ananatis. J. Clin. Microbiol. 42, 4393-4395. doi: 10.1128/jcm.42.9.4393-4395.2004

Dean, R., Van Kan, J. A. L., Pretorius, Z. A., Hammond-Kosack, K. E., Di Pietro, A., Spanu, P. D., et al. (2012). The Top 10 fungal pathogens in molecular plant pathology. Mol. Plant Pathol. 13, 414-430. doi: 10.1111/j.1364-3703.2011. 00783.x

Dickie, G. A., and Bell, C. R. (1995). A full factorial analysis of nine factors influencing in vitro antagonistic screens for potential biocontrol agents. Can. J. Microbiol. 41, 284-293. doi: 10.1139/m95-039

Durán, P., Thiergart, T., Garrido-Oter, R., Agler, M., Kemen, E., Schulze-Lefert, P., et al. (2018). Microbial interkingdom interactions in roots promote Arabidopsis survival. Cell 175, 973-983. doi: 10.1016/j.cell.2018.10.020

Failor, K. C., Schmale, D. G. III, Vinatzer, B. A., and Monteil, C. L. (2017). Ice nucleation active bacteria in precipitation are genetically diverse and nucleate ice by employing different mechanisms. ISME J. 11, 2740-2753. doi: 10.1038/ ismej.2017.124

Felnagle, E. A., Jackson, E. E., Chan, Y. A., Podevels, A. M., Berti, A. D., McMahon, M. D., et al. (2008). Nonribosomal peptide synthetases involved in the production of medically relevant natural products. Mol. Pharm. 5, 191-211. doi: $10.1021 / \mathrm{mp} 700137 \mathrm{~g}$

Förster, H., McGhee, G. C., Sundin, G. W., and Adaskaveg, J. E. (2015). Characterization of streptomycin resistance in isolates of Erwinia amylovora in California. Phytopathology 105, 1302-1310. doi: 10.1094/PHYTO-03-150078-R

Gerami, E., Hasanzadeh, N., Abdollahi, H., Ghasemi, A., and Heydari, A. (2013). Evaluation of some bacterial antagonists for biological control of fire blight disease. J. Plant Pathol. 95, 127-134. doi: 10.1094/PHYTO.1997.87.11.1096

Giddens, S. R., Feng, Y., and Mahanty, H. K. (2002). Characterization of a novel phenazine antibiotic gene cluster in Erwinia herbicola Eh1087. Mol. Microbiol. 45, 769-783. doi: 10.1046/j.1365-2958.2002.03048.x
Ishimaru, C. A., Klos, E. J., and Brubaker, R. R. (1988). Multiple antibiotic production by Erwinia herbicola. Phytopathology 78, 746-750.

Jaffuel, G., Imperiali, N., Shelby, K., Campos-Herrera, R., Geisert, R., Maurhofer, M., et al. (2019). Protecting maize from rootworm damage with the combined application of arbuscular mycorrhizal fungi, Pseudomonas bacteria and entomopathogenic nematodes. Sci. Rep. 9, 3127. doi: 10.1038/s41598-01939753-7

Johnson, K. B., Stockwell, V. O., Sawyer, T. L., and Sugar, D. (2000). Assessment of environmental factors influencing growth and spread of Pantoea agglomerans on and among blossoms of pear and apple. Phytopathology 90, 1285-1294. doi: 10.1094/PHYTO.2000.90.11.1285

Karnetová, J., Tax, J., Stajner, K., Vanik, Z., and Krumphanzl, V. (1983). Production of phenazines by Streptomyces cinnamonensis. Folia Microbiol. (Praha) 28, 51-53. doi: $10.1007 /$ bf02877385

Kim, D., Langmead, B., and Salzberg, S. L. (2015). HISAT: a fast spliced aligner with low memory requirements. Nat. Methods 12:357. doi: 10.1038/nmeth.3317

Kloepper, J. W., Leong, J., Teintze, M., and Schroth, M. N. (1980). Pseudomonas siderophores: a mechanism explaining disease-suppressive soils. Curr. Microbiol. 4, 317-320. doi: 10.1007/bf02602840

Koboldt, D. C., Chen, K., Wylie, T., Larson, D. E., McLellan, M. D., Mardis, E. R., et al. (2009). VarScan: variant detection in massively parallel sequencing of individual and pooled samples. Bioinformatics 25, 2283-2285. doi: 10.1093/ bioinformatics/btp373

Koczan, J. M., Lenneman, B. R., McGrath, M. J., and Sundin, G. W. (2011). Cell surface attachment structures contribute to biofilm formation and xylem colonization by Erwinia amylovora. Appl. Environ. Microbiol. 77, 7031-7039. doi: 10.1128/AEM.05138-11

La Fuente, L. D., Thomashow, L., Weller, D., Bajsa, N., Quagliotto, L., Chernin, L., et al. (2004). Pseudomonas Fluorescens UP61 isolated from birdsfoot trefoil rhizosphere produces multiple antibiotics and exerts a broad spectrum of biocontrol activity. Eur. J. Plant Pathol. 110, 671-681. doi: 10.1023/b:ejpp. 0000041569.35143 .22

Lee, H. B., Hong, J. P., and Kim, S. B. (2010). First report of leaf blight caused by Pantoea agglomerans on rice in Korea. Plant Dis. 94, 1372-1372. doi: 10.1094/ PDIS-05-10-0374

Li, H., Handsaker, B., Wysoker, A., Fennell, T., Ruan, J., Homer, N., et al. (2009). The sequence Alignment/Map format and SAMtools. Bioinformatics 25, 2078 2079. doi: 10.1093/bioinformatics/btp352

Lindow, S. E. (1983). The role of bacterial ICE nucleation in frost injury to plants. Annu. Rev. Phytopathol. 21, 363-384. doi: 10.1146/annurev.py.21.090183. 002051

Lindow, S. E. (1991). "Determinants of epiphytic fitness in bacteria," in Microbial Ecology of Leaves, eds J. H. Andrews, and S. S. Hirano, (New York, NY: Springer), 295-314. doi: 10.1007/978-1-4612-3168-4_15

Lindow, S. E. (1993). Novel method for identifying bacterial mutants with reduced epiphytic fitness. Appl. Environ. Microbiol. 59, 1586-1592.

Loper, J. E., Henkels, M. D., Roberts, R. G., Grove, G. G., Willet, M. J., and Smith, T. J. (1991). Evaluation of streptomycin, oxytetracycline and copper resistance of Erwinia amylovora isolated from pear orchards in Washington State. Plant Dis. 75, 287-290.

Matyjaszczyk, E. (2015). Products containing microorganisms as a tool in integrated pest management and the rules of their market placement in the European Union. Pest Manag. Sci. 71, 1201-1206. doi: 10.1002/ps.3986

McManus, P. S., and Jones, A. L. (1994). Epidemiology and genetic analysis of streptomycin-resistant Erwinia amylovora from Michigan and evaluation of oxytetracycline for control. Phytopathology 84, 627-633.

McMurdie, P. J., and Holmes, S. (2013). phyloseq: an R package for reproducible interactive analysis and graphics of microbiome census data. PLoS One 8:e61217. doi: 10.1371/journal.pone.0061217

Medema, M. H., Blin, K., Cimermancic, P., de Jager, V., Zakrzewski, P., Fischbach, M. A., et al. (2011). antiSMASH: rapid identification, annotation and analysis of secondary metabolite biosynthesis gene clusters in bacterial and fungal genome sequences. Nucleic Acids Res. 39, W339-W346. doi: 10.1093/nar/gkr466

Mora, I., Cabrefiga, J., and Montesinos, E. (2015). Cyclic lipopeptide biosynthetic genes and products, and inhibitory activity of plant-associated Bacillus against phytopathogenic bacteria. PLoS One 10:e0127738. doi: 10.1371/journal.pone. 0127738 
Neeno-Eckwall, E. C., Kinkel, L. L., and Schottel, J. L. (2001). Competition and antibiosis in the biological control of potato scab. Can. J. Microbiol. 47, 332-340. doi: 10.1139/w01-010

Norelli, J. L., Jones, A. L., and Aldwinckle, H. S. (2003). Fire blight management in the twenty-first century: using new technologies that enhance host resistance in apple. Plant Dis. 87, 756-765. doi: 10.1094/pdis.2003.87.7.756

Nuclo, R. L., Johnson, K. B., Stockwell, V. O., and Sugar, D. (1998). Secondary colonization of pear blossoms by two bacterial antagonists of the fire blight pathogen. Plant Dis. 82, 661-668. doi: 10.1094/PDIS.1998.82.6.661

Özaktan, H., Bora, T., Sukan, S., Sargin, S., and Vardar Sukan, F. (1999). Studies on determination of antagonistic potential and biopreparation of some bacteria against the Fireblight pathogen. Acta Hortic. 489, 663-668. doi: 10.17660/ actahortic.1999.489.118

Pieterse, C. M. J., Zamioudis, C., Berendsen, R. L., Weller, D. M., Van Wees, S. C. M., and Bakker, P. A. H. M. (2014). Induced systemic resistance by beneficial microbes. Annu. Rev. Phytopathol. 52, 347-375. doi: 10.1146/ annurev-phyto-082712-102340

Polymenakou, P. N. (2012). Atmosphere: a source of pathogenic or beneficial microbes? Atmosphere 3, 87-102. doi: 10.3390/atmos3010087

Pujol, M., Badosa, E., Manceau, C., and Montesinos, E. (2006). Assessment of the environmental fate of the biological control agent of fire blight, Pseudomonas fluorescens; EPS62e, on apple by culture and real-time PCR methods. Appl. Environ. Microbiol. 72, 2421-2427. doi: 10.1128/aem.72.4.2421-2427.2006

Pusey, L. P. (1999). Laboratory and field trials with selected microorganisms as biocontrol agents for fire blight. Acta Hortic. 489, 655-661.

Quast, C., Pruesse, E., Yilmaz, P., Gerken, J., Schweer, T., Yarza, P., et al. (2013). The SILVA ribosomal RNA gene database project: improved data processing and web-based tools. Nucleic Acids Res. 41, D590-D596. doi: 10.1093/nar/gks 1219

Reganold, J. P., and Wachter, J. M. (2016). Organic agriculture in the twenty-first century. Nat. Plants 2:15221. doi: 10.1038/nplants.2015.221

Rezzonico, F., Smits, T. H. M., Montesinos, E., Frey, J. E., and Duffy, B. (2009). Genotypic comparison of Pantoea agglomerans plant and clinical strains. BMC Microbiol. 9:204. doi: 10.1186/1471-2180-9-204

Roselló, G., Bonaterra, A., Francés, J., Montesinos, L., Badosa, E., and Montesinos, E. (2013). Biological control of fire blight of apple and pear with antagonistic Lactobacillus plantarum. Eur. J. Plant Pathol. 137, 621-633. doi: 10.1007/ s10658-013-0275-7

RStudio (2015). RStudio: Integrated Development for R. Boston, MA: RStudio, Inc.

Russo, N. L., Burr, T. J., Breth, D. I., and Aldwinckle, H. S. (2008). Isolation of streptomycin-resistant isolates of Erwinia amylovora in New York. Plant Dis. 92, 714-718. doi: 10.1094/pdis-92-5-0714

Seemann, T. (2014). Prokka: rapid prokaryotic genome annotation. Bioinformatics 30, 2068-2069. doi: 10.1093/bioinformatics/btu153

Sharifazizi, M., Harighi, B., and Sadeghi, A. (2017). Evaluation of biological control of Erwinia amylovora, causal agent of fire blight disease of pear by antagonistic bacteria. Biol. Control 104, 28-34. doi: 10.1016/j.biocontrol.2016. 10.007

Smits, T. H., Rezzonico, F., Blom, J., Goesmann, A., Abelli, A., Kron Morelli, R., et al. (2015). Draft genome sequence of the commercial biocontrol strain Pantoea agglomerans P10c. Genome Announc. 3:e01448-15. doi: 10.1128/ genomeA.01448-15

Stockwell, V. O., Johnson, K. B., and Loper, J. E. (1998). Establishment of bacterial antagonists of Erwinia amylovora on pear and apple blossoms as influenced by inoculum preparation. Phytopathology 88, 506-513. doi: 10.1094/PHYTO.1998. 88.6.506

Sundin, G. W., and Wang, N. (2018). Antibiotic resistance in plant-pathogenic bacteria. Annu. Rev. Phytopathol. 56, 161-180. doi: 10.1146/annurev-phyto080417-045946

Sundin, G. W., Werner, N. A., Yoder, K. S., and Aldwinckle, H. S. (2009). Field evaluation of biological control of fire blight in the eastern United States. Plant Dis. 93, 386-394. doi: 10.1094/PDIS-93-4-0386

Tancos, K. A., Villani, S., Kuehne, S., Borejsza-Wysocka, E., Breth, D., Carol, J., et al. (2015). Prevalence of streptomycin-resistant Erwinia amylovora in New York apple orchards. Plant Dis. 100, 802-809. doi: 10.1094/PDIS-09-15-0960-RE

Temple, T. N., Stockwell, V. O., Loper, J. E., and Johnson, K. B. (2004). Bioavailability of iron to Pseudomonas fluorescens strain A506 on flowers of pear and apple. Phytopathology 94, 1286-1294. doi: 10.1094/PHYTO.2004.94. 12.1286

Thomashow, L. S., and Weller, D. M. (1988). Role of a phenazine antibiotic from Pseudomonas fluorescens in biological control of Gaeumannomyces graminis var. tritici. J. Bacteriol. 170, 3499-3508. doi: 10.1128/jb.170.8.3499-3508. 1988

Thomson, S. V. (1985). The role of the stigma in fire blight infections. Phytopathology 76, 476-482.

Tian, L., Huang, C., Heath, L. S., and Vinatzer, B. A. (2019). LINbase: a web service for genome-based identification of microbes as members of crowdsourced taxa. bioRxiv [Preprint]. doi: 10.1101/752212

Van Wees, S. C. M., Pieterse, C. M. J., Trijssenaar, A., Van 't Westende, Y. A. M., Hartog, F., and Van Loon, L. C. (1997). Differential induction of systemic resistance in Arabidopsis by biocontrol bacteria. Mol. Plant Microbe Interact. 10, 716-724. doi: 10.1094/mpmi.1997.10.6.716

Wei, F., Hu, X., and Xu, X. (2016). Dispersal of Bacillus subtilis and its effect on strawberry phyllosphere microbiota under open field and protection conditions. Sci. Rep. 6:22611. doi: 10.1038/srep22611

Weißhaupt, S., Köhl, L., Kunz, S., Hinze, M., Ernst, M., Schmid, A., et al. (2016). Alternative inoculum sources for fire blight: the potential role of fruit mummies and non-host plants. Plant Pathol. 65, 470-483. doi: 10.1111/ppa.12431

Wick, R. R., Judd, L. M., Gorrie, C. L., and Holt, K. E. (2017). Unicycler: resolving bacterial genome assemblies from short and long sequencing reads. PLoS Comput. Biol. 13:e1005595. doi: 10.1371/journal.pcbi.1005595

Wick, R. R., Schultz, M. B., Zobel, J., and Holt, K. E. (2015). Bandage: interactive visualization of de novo genome assemblies. Bioinformatics 31, 3350-3352. doi: 10.1093/bioinformatics/btv383

Wilson, M., Epton, H. A. S., and Sigee, D. C. (1992a). Biological control of fire blight of hawthorn (Crataegus monogyna) with fluorescent Pseudomonas spp. under Protected Conditions. J. Phytopathol. 136, 16-26. doi: 10.1111/j.14390434.1992.tb01277.x

Wilson, M., Epton, H. A. S., and Sigee, D. C. (1992b). Interactions between Erwinia herbicola and E. amylovora on the stigma of hawthorn blossoms. Phytopathology 82, 914-918.

Wilson, M., and Lindow, S. E. (1992). Interactions between the biological control agent Pseudomonas fluorescens A506 and Erwinia amylovora in pear blossoms. Phytopathology 83, 117-123.

Wilson, M., and Lindow, S. E. (1994). Inoculum density-dependent mortality and colonization of the phyllosphere by Pseudomonas syringae. Appl. Environ. Microbiol. 60, 2232-2237. doi: 10.1128/aem.60.7.2232-2237.1994

Wright, S. A. I., Zumoff, C. H., Schneider, L., and Beer, S. V. (2001). Pantoea agglomerans strain EH318 produces two antibiotics that inhibit Erwinia amylovora in vitro. Appl. Environ. Microbiol. 67, 284. doi: 10.1128/aem.67.1. 284-292.2001

Wu, L., Liu, R., Niu, Y., Lin, H., Ye, W., Guo, L., et al. (2016). Whole genome sequence of Pantoea ananatis R100, an antagonistic bacterium isolated from rice seed. J. Biotechnol. 225, 1-2. doi: 10.1016/j.jbiotec.2016.03.007

Conflict of Interest: LINbase uses the trademarks Life Identification Number ${ }^{\circledR}$ and LIN $^{\circledR}$, which are registered by this Genomic Life, Inc. BV reports in accordance with Virginia Tech policies and procedures and his ethical obligation as researcher that he has a financial interest in this Genomic Life, Inc. Therefore, his financial interests may be affected by the research reported in this manuscript. He has disclosed those interests fully to Virginia Tech, and he has in place an approved plan for managing any potential conflicts arising from this relationship.

The remaining authors declare that the research was conducted in the absence of any commercial or financial relationships that could be construed as a potential conflict of interest.

Copyright (c) 2020 Mechan Llontop, Hurley, Tian, Bernal Galeano, Wildschutte, Marine, Yoder and Vinatzer. This is an open-access article distributed under the terms of the Creative Commons Attribution License (CC BY). The use, distribution or reproduction in other forums is permitted, provided the original author(s) and the copyright owner(s) are credited and that the original publication in this journal is cited, in accordance with accepted academic practice. No use, distribution or reproduction is permitted which does not comply with these terms. 